\title{
A short chronicle of warfare in South Africa
}

\section{Compiled by the Military Information Bureau*}

\begin{abstract}
Khoisan Wars
Khoisan is the collective name for the South African people known as Hottentots and Bushmen. It is compounded from the first part of Khoi Khoin (men of men) as the Hottentots called themselves, and San, the names given by the Hottentots to the Bushmen. The Hottentots and Bushmen were the first natives Dutch colonist encountered in South Africa. Both had a relative low cultural development and may therefore be grouped. The Colonists fought two wars against the Hottentots while the struggle against the Bushmen was manned by casual ranks on the colonist farms.
\end{abstract}

\section{The KhoiKhoi Wars}

\section{1st Khoikhoi War (1659-1660)}

This was the first violent reaction of the Khoikhoi (Hottentots or Capemen) to European occupation and cultivation of their old grazing lands. The fighting was of a very desultory nature, consisting largely of raids on the cattle of the colonists and futile attempts by the whites to trace the perpetrators of these. There was relatively little bloodshed on either side: one colonist and six Khoikhoi were killed.

\section{2nd Khoikhoi War (1673-1677)}

This far more serious conflict started with an attack by a Khoikhoi clan on settlers from Saldanha Bay area, in an attempt to regain control of its old lands. Certain Khoikhoi clans joined the colonist and in the following years several commandos were sent out, resulting in considerable loss to the Khoikhoi.

\section{San Wars (1668-1861)}

In 1676 three burghers were killed at Breede Rivier by a party of San (Bushmen). Primitive commandos were organised by soldiers, burghers and Khoikhoi but achieved no success.

These operations formed part of the 2nd Khoikhoi war, since the San were regarded as dependants of the Khoikhoi clan involved, but also mark the beginning of a series of clashes be- tween whites, Khoikhoi and slaves on the one side and the nomadic San hunters on the other which was to last for almost 200 years. In general actions consisted of raids on cattle by the San and of punitive commandos which aimed at nothing short of the extermination of the San themselves. On both sides the fighting was ruthless and extremely destructive of both life and property.

During 18th century the threat increased to such an extent that the Government had to reissue the defence-system. Commandos were sent out and eventually the Bushmen threat was overcome.

\section{The Frontier War (1779-1878)}

This term is used to cover the nine so-called "Kaffir Wars" which took place on the eastern border of the Cape between the Cape government and the Xhosa. This series of conflicts was an inevitable result of the contact between the trekboere and the pastoral Xhosa tribes of the Zuurveld, an area bordered by the coast and the lines of the Bushmans and Upper Fish Rivers. Attempts were made by successive governments to establish a firm boundary separating the areas of white and black settlement and in 1775 the Bushman's and Upper Fish Rivers were defined as the border, leaving the Zuurveld in Xhosa hands.

The Xhosas were a constant menace to the Frontier farmers but on the rare occasions when they could be cornered, could do nothing against the buckshot and bullets of the commandos as they carried no fire arms.

\section{1st Frontier War (1779-1781)}

In 1778 Governor van Plettenberg found Xhosas and Boere living on both sides of the 1775 frontier and tried unsuccessfully to persuade both sides to respect the boundary line. In 1779 a series of skirmishes erupted along the border and the Boere began to abandon their farms. In 1780 the Cape government unlaterally redefined its eastern boundary as the Fish River, thus laying claim to most of the Zuurveld. Commandos took the field, burghers along with their coloured slaves and servants and by 1781 these had driven the Xhosa across the new frontier. 


\section{2nd Frontier War (1789-1793)}

Frontier conditions remained insecure and by 1789 raiding and counter-raiding in the Zuurveld was again general. By 1793 the conflict had grown in scale to include the Gunukwebe tribe who were at war with Ndlambe's Western Xhosa. Even extensive commando operations were unable to clear the Zuurveld and the peace of 1793 merely recognised the state of stalemate which now existed.

\section{3rd Frontier War (1799-1803)}

Boer and Xhosa contact and friction in the Zuurveld area continued through the 1790's. Local colonists, dissatisfied with the new British government's frontier policy rebelled in Graaff-Reinet and British troops were sent to quell the troubles in 1799. By April that year discontented Khoikhoi (Hottentots) had also gone into revolt and joined the Xhosas in attacks on White farms. The Gunukwebe also made serious attacks on British forces. Commandos were raised and a series of skirmishes took place. Fear of a general Khoikhoi rising forced the government to make peace and to allow the Xhosa to remain in the Zuurveld. Another rebellion in Graaff-Reinet resulted in 1801, and Khoikhoi bands again took the field to carry out widespread raids. Commandos once more undertook extensive operations with little result and the peace of 1803 was an inconclusive one.

\section{4th Frontier War (1811-1812)}

Continued insecurity and tension along the eastern frontier led the Imperial authorities to decide on the expulsion of the Xhosa and Gunukwebe from the Zuurveld in 1811. In 1812 British and colonial forces evicted large numbers of tribesmen and a line of frontier forts was built.

\section{5th Frontier War (1819-????)}

Tensions on the frontier led to a renewal of civil war between Gaika's and Ndlambe's Xhosa. Gaika appealed to the Cape government for help and colonial forces entered Xhosa territory and defeated Ndlambe. The latter, however, again defeated Gaika and invaded the colony. An attack on Grahamstown was repulsed and Ndlambe was driven to the Kei River. In October 1819 the chiefs were compelled to recognise Gaika's claim as paramount chief of the Western Xhosa. A strip of neutral territory was demarcated and the Zuurveld was later populated by the 1820 Settlers.

\section{6th Frontier War (1834-1835)}

By 1830 the Cape's eastern frontier lay along the Keiskamma River. Whites, Khoikhoi and Xhosa were once again living in the border territories and insecurity and tension persisted. The vacillations of government policy added to the uncertainty and bitterness among the Xhosa. Large scale cattle thefts were followed by harsh military reprisals and at the end of 1834 a large force of Xhosa swept into Cape territory. After extensive military operations the invasion was defeated and the newly-named Queen Adelaide districts temporarily annexed to the colony.

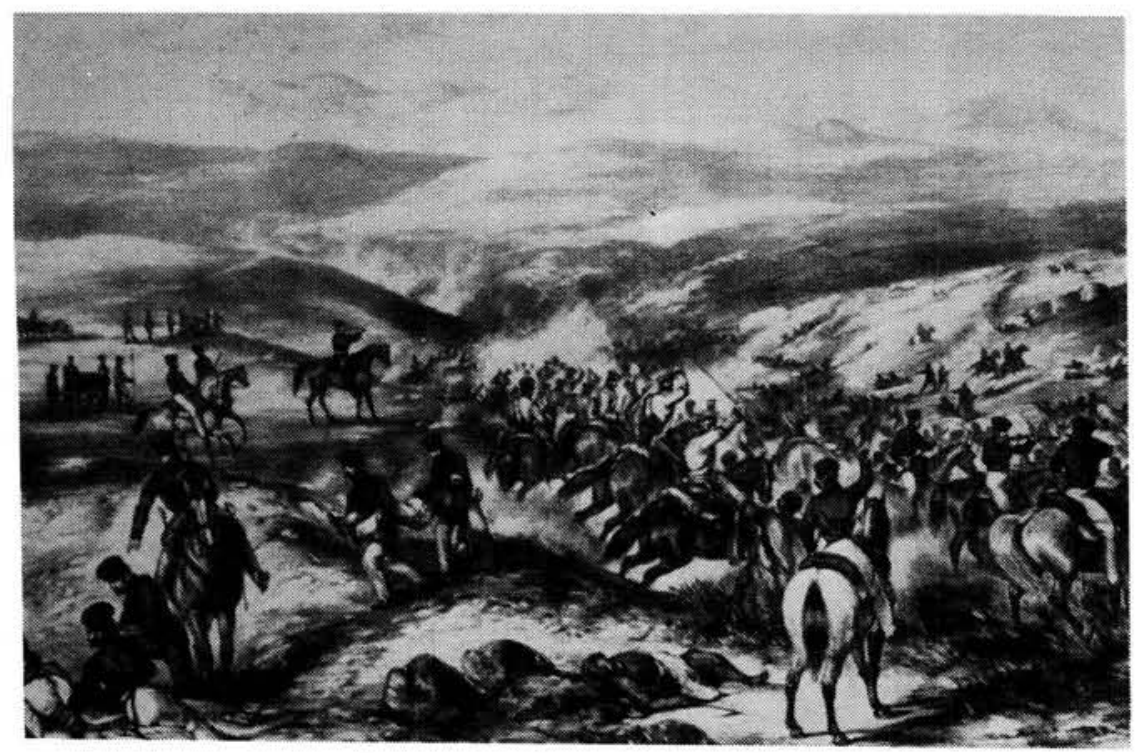

The Battle of Gwangwa, 8 June 1846 


\section{7th Frontier War (War of the Axe' 1846-1847)}

Cattle theft and unrest persisted through the early 1840's, with the Cape encroaching on Xhosa sovereignty by means of patrol and the establishment of forts. An attempt to arrest a
Xhosa for the theft of an axe led to an attack on a patrol, the invasion of the colony and cattle raiding. Mfengu (Fingo) irregulars aided the colonial authorities but only after a protracted and bitter "scorched earth" campaign did the Xhosa submit.

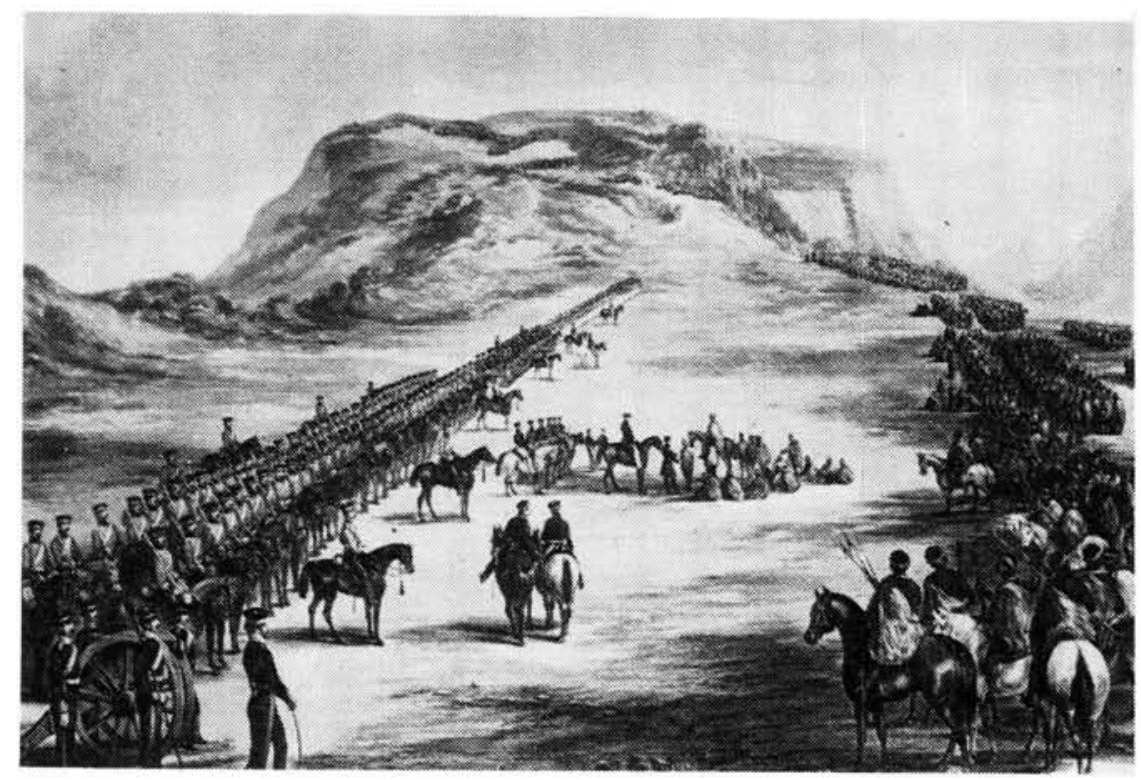

The meeting of Sandili and Col John Hare at Black Drift, 30 January 1846

\section{8th Frontier War (1850-1853)}

The subsequent extension of the Cape frontier to the Keiskamma River created considerable pressure on Xhosa resource and a new resistance movement began which took fire when Sandile, chief of the Gaika Xhosa, was deposed by the colonial authorities in October 1850. Colonial troops were attacted and the Gaikas received help from the Thembu, some Galekas, Black police and Khoikhoi from Kat River. The Kat River rebellion was quickly suppressed and the colonial forces were joined by other Khoikhoi, and the Ndlambe Xhosa and the Mfengu. Once again Xhosa resistance was only overcome after an arduous and costly campaign.

\section{9th Frontier War (1877-1878)}

Feelings between the Mfengu and their Galeka Xhosa neighbours were never control, and a quarrel at an Mfengu wedding feast precipitated general conflict. The Mfengu were joined by the Thembu and by colonial troops but the Galekas were aided by the Gaikas. A serious war developed but eventually the Xhosa were defeated and their territories brought under colonial control.

\section{British occupation of the Cape}

The French revolutionary wars lead to the occupation of the Cape in 1795 and 1806. The first capture of the Cape was only achieved after a number of sharp engagements in 1795. Returnal to the Dutch authorities by the Peace of Armiers in 1803 , it was seized a second time in 1806 after a series of clashes.

\section{Cape Frontier Rebellions (1795-???)}

(i) Graaff-Reinet and Swellendam Rebellions (1795). These were provoked by differences between local farmers and the authorities over the proper policy towards the frontier area. Attempts were made to achieve full local self-government by the proclamation of independent republics. The two republics were short lived and came to an end during the first British occupation of the Cape on 16 September 1795 (no casualted).

(ii) Slagters Nek Rebellion 18 November 1815 9 March 1816. This was precipitated by the government's use of coloured troops to arrest a white farmer, an incident which ignited the old differences over "native policy". Jo- 
hannes Bezuidenhout was killed during the clash between the Government forces and the rebels. During a trail four of the accused were sentenced to death and hung on 9 March 1816.

\section{Mfecane (Also known as Difaqane in Sotho dialect)}

This general name meaning "forced migration" refers to one of the most chaotic and violent periods of South African history just before and after 1820. The rise of the centralised Zulu kingdom triggered off a chain of wars and migrations across most of southern Africa and resulted in devastation on a scale previously unparalleled in tribal warfare.

\section{Battles of the Great Trek (1836-1840)}

In 1936 the first Voortrekker parties passed through Ndebele territory. The Ndebele had long been in conflict with Griqua invaders and eventually attacked the Boers. Several major engagements occurred, the Boers being joined by other enemies of other enemies of the Ndebele: the Griqua, Thokwa and even the Zulu. The Ndebele were defeated in a protracted and destructive campaign, and were driven across the Limpopo.

\section{The conflict with the Zulu}

It began with the killing of Piet Retief and his companions and the subsequent attack on Boer settlements. Boer forces severely damaged the Zulu military power at Blood River, but the defeat of Dingane was only fully accomplished when Mpande defected to the Boers with large numbers of his fellow tribesmen and destroyed Dingane's power at the severe battle of Magongo.

In Natal Pretorius assumption that Ncaphayi's Bhaca were responsible for the theft of Boer cattle, led to a punitive raid killing some 30 tribesmen in December 1840.

\section{Voortrekker versus British in Natal (1842)}

Imperial troops marched into Natal in 1842 after alarms from the Mpondo about the Voortrekker's policy towards them. The Volksraad determined to resist this incursion and after the action at Congella besieged a British force which had made a landing on the Natal coast. Eventually a political settlement was negotiated which resulted in the British annexation of the territory.

\section{Voortrekker British conflict in O.F.S. (1845-1848)}

Trekker resistance against Adam Kok led to defeat by British troops at Swartkoppies in May 1845. The annexation of the Orange River territory by Britain in 1848 met with violent opposition from the Trekkers. Pretorius was defeated at Boomplaats in August of the same year and most of the Trekkers left for the Transvaal area.

\section{Basotho Wars (1851-1868)}

Maj $\mathrm{H}$. Warden was defeated at Viervoet in June 1851 after a futile attempt to force his bardet regulations on the Basotho. Cathcart made a second attempt to subdue Mosheshwe but suffered defeat at Bereaberg on 20 December 1852.

Disputes over boundaries as well as continuous raids into the Orange Free State by the Basotho caused several serious clashes with the Free State Government. A continuation of the Free State-Basotho struggle was inevitable. Commandos began a systematic reduction of Mosheshwe's fortresses and though the central stronghold of Thaba Bosigo held out, Mosheshwe had to appeal for an end to hostilities in 1866. There was a brief truce but hostilities recommenced shortly afterwards and Mosheshwe was only saved by his submission to British rule in March 1868.

\section{Cape versus Basotho Wars (1879-1898)}

In 1879 the Cape government, now the authority of Basutoland, decided to disarm certain colonial tribes. Moorosi, a Phuthi chief of the south of Basutoland, defied the authorities and only after a campaign of six months in which the colonial forces were assisted by letsie's Basotho, was Moorosi defeated and killed. Next year the Cape government's decision to disarm the southern Sotho and extend white settlement in some areas led to a fullscale rising which spread to the Thembu and Griqua. An unsatisfactory peace was made in 1881.

After continued violence caused by the rivalries between the various Sotho chiefs, Basutoland was formally taken over by the Imperial author- 
ities in 1884. Chief Muropha continued to defy the paramountary of Chief letsie and later lerotholi who were supported by the Imperial Government. In 1898 the Marophu was finally defeated by lerotholi.

\section{Boer-Pedi War (1847-1852)}

The Boers claim to the land west of the Steelpoort River was rejected by Sekwati's Pedi. Hostilities between Boers and Pedi began in 1847 and in 1852 a Boer commando besieged the stat at Phiring. The Pedi survived the seige and withdrew to Mosega near the Lulu Mountains.

\section{Makepane War (1845)}

In retaliation for the massacre of a hunting expedition by Makapane's Sotho a Boer commando blockaded many of Makapane's people in a cavern and killed some 3000 of them.

\section{The Mahura War (1858)}

As a result of cattle-raiding by the Korana into the Free State, the republic organised a commando which, with Mfengu and Korana allies defeated the raiders. The raiders' Batlapin allies meanwhile were attacked by a ZAR commando and heavily defeated.

\section{Venda and Sotho Wars (1859-1867)}

Attacks by the newly-appointed commissioner Albasini on Venda villages in 1859 provoked that tribe into raiding white farms. For some time the republican authorities struggled to raise commandos to fight in the Soutpansberg but in 1867 Kruger was forced to abandon Schoemansdal to the Venda. Makapane and other Sotho chiefs now joined in harassing the whites and successfully drove the settlers out of most of the Soutpansberg.

\section{Zulu-Civil War}

While Mpande was still alive the Usutu and Usibepu factions were already fighting for the succession to his chiefdom. After a full-scale battle Cetshwayo, head of the Usutu faction assumed the regency
Following Cetshwayo's return from exile in 1883 the old rivalry between the Usutu and Usibebu factions flared once more. Aided by Boer freebooters the Usutu eventually gained the upper hand, but only at the cost of much of their territory. Dinuzulu succeeded his father as paramount chief over what remained of Zululand, in 1883.

\section{Pedi-Civil War (1861)}

On the death of Sekwati a civil war ensued among the Pedi in which Sekhukhune emerged victorius over Mamputu.

\section{ZAR-Pedi War (1876) (1st Sekhukhune War)}

The Pedi chief Sekhukhune refused to acknowledge the ZAR's sovereignty over his territory. Raids on Boer cattle also disturbed the farmers and eventually President Burger led a force of commandos and Swazi against Sekukhune's stronghold in the lulu Mountains. The campaign began very badly but eventually Sekhukhune made a pretence of submission.

\section{Anglo-Pedi War (1878-1879) (2nd Sekhukhune War)}

After the British annexation of the Transvaal the Pedi again began to act independently. British operations against him were delayed by the Zulu conflict but in November 1879 British troops stormed Sekhukhune's stronghold and deposed him.

\section{Langalibalele War (1873)}

An attempt to compel the obedience of Langalibalele the Hlubi chief, to the Natal government, led to a protracted and difficult campaign, before the "rising" was suppressed and Langalibalele handed over to the British by Molapo.

\section{Anglo-Zulu War (1879)}

By 1878 the British authorities in South Africa had decided that an end must be made of the independent Zulu military machine. Following an ultimatum to Cetshwayo British troops invaded Zululand, aided by colonial auxiliaries. The British suffered heavy defeats at Isandhlwana where almost a complete battallion was wiped out. 


\section{Zulu uprising (1888)}

By 1888 the British administration had decided to employ force to curb what was seen as incipient Usutu rebellion in Zululand. After a series of clashes Dinuzulu was arrested and exiled to St Helena.

\section{Zululand Rebellion (1906)}

The imposition of a new poll tax by the Natal government in 1905 led to a great deal of dissatisfaction among the Zulu. The magistrates were defied and eventually Bambata, a deposed chief rallied thousands of Zulu in resistance to the authorities. The Natal forces, aided by volunteers from other parts of South Africa quickly suppressed the rising in a series of bloody encounters. 30 Europeans and 3000 Zulu's were killed in the Bambata Rebellion.

\section{Griqualand West Rebellion (1877-1878)}

Discontent about the new dispensation on the Diamond Fields eventually led to sporadic violence from the Griqua, Khoikhoi and Tswana inhabitants. This was eventually suppressed by colonial volunteers with heavy loss of life.

\section{Tswana Frontier Wars (1881-1885)}

Conflict between the Korana of Mamusa and the Thaping at Taungs, and between the Ratlou-Rolong and the Tshidi-Rolong soon involved white freebooters on both sides. The conflict was briefly ended in 1884 by Imperial intervention and the eviction of the freebooters, but in 1885 the ZAR and the Kore again came to blows and the tribe was dispersed.

\section{ZAR-Mabogho War (1882-1883) (Mapoch War)}

Nyabela, chief of the Mabogho clan of Ndebele sheltered a fugitive Bepedi chief from the ZAR authorities. Commandos aided by Pedi auxiliaries eventually smashed the clan after an eight month siege and apprenticed the survivors to farmers.

\section{ZAR-Lobedu War (1890) (Modjadji War)}

Discontent among the Lobedu in the north of the Transvaal alarmed the local ZAR officials who gathered some thousand of "loyal" Shangaan to help suppress any outbreak. Commandos were also dispatched to the scene of the unrest and eventually an attack was made on a Lobedu village. This led to the capitulation of Queen Modjadji.

\section{ZAR-Lobedu War (1894-1895) (Magoesa War)}

Lobedu resistance to White settlement of the Woodbush area led to the dispatch of commandos which, with the assistance of Shangaan auxiliaries suppressed the "rebellion" after a protracted campaign.

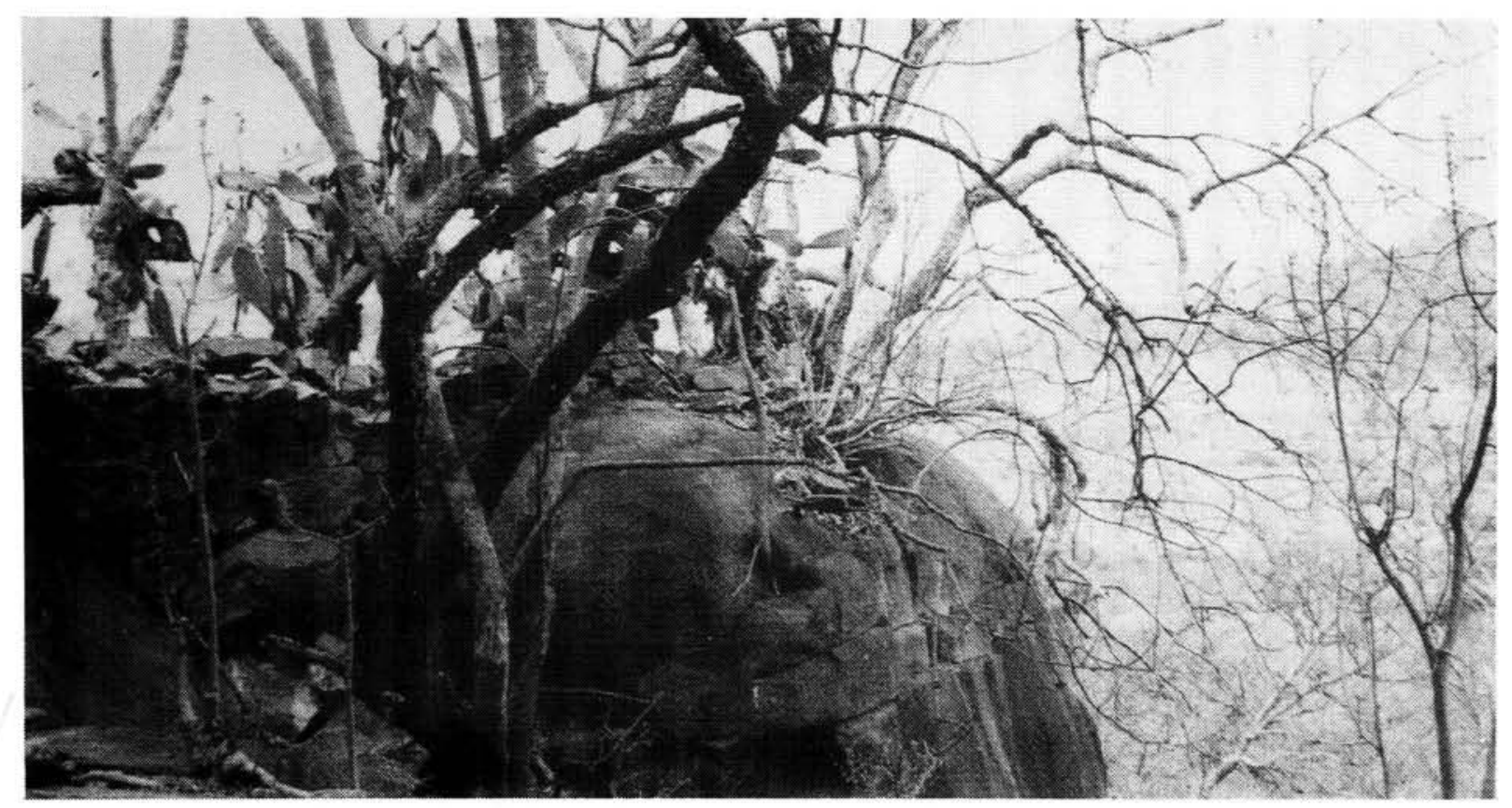

The inaccessable mountain stronghold of the Mapoch Chief Nyabela 


\section{ZAR-Malaboch War (1894)}

Malaboch, chief of a minor Northern Sotho group living in the northern Transvaal, earned the displeasure of the authorities through his refusals to pay tax and alleged cattle-thieving. An ultimatum to the chief failed to have the desired effect and eventually the tribe was defeated by force of arms and the captives dispersed as apprentices.

\section{ZAR-Venda War (1898) (Magalo War of Mphephu War)}

The death of the Venda chief Machado in 1895 led to a succession dispute in which the ZAR authorities backed the claims of Sinthumule against those of Mphephu. Commandos were sent in with Swazi and Tsonga allies to storm Mphephu's stronghold. Mphephu was defeated and driven across the Limpopo into Shona territory.

\section{Transvaal Civil War (1862-1864)}

Religious and political differences between the various Voortrekker groups and their leaders finally boiled over in 1857 when Schoeman declared war on Pretorius. By the time the conflict ended in 1875 there had been relatively little bloodshed.

\section{Jameson Raid 29 Dec 1695 - Jan 1895}

In 1895 certain Transvaal mining interests began a plot to subvert the Kruger government. An essential part of the plan was for Dr Jameson to cross the ZAR border with a force of Bechuanaland Border Police and ride to Johannesburg to aid the insurrectionists. Near Krugersdorp Jameson's force met the mobilised Boer commandos and fighting began which ended next day with Jameson's surrender.

\section{First War of Independence (1880-1881)}

Late in 1880 Boer passive resistance to the British administration of the Transvaal developed into armed resistance. The British garrisons were quickly besieged in their towns and the relieving forces under General Colley were prevented from entering the Transvaal. Eventually terms were agreed which included the retrocession of the Transvaal to the Republican leaders.

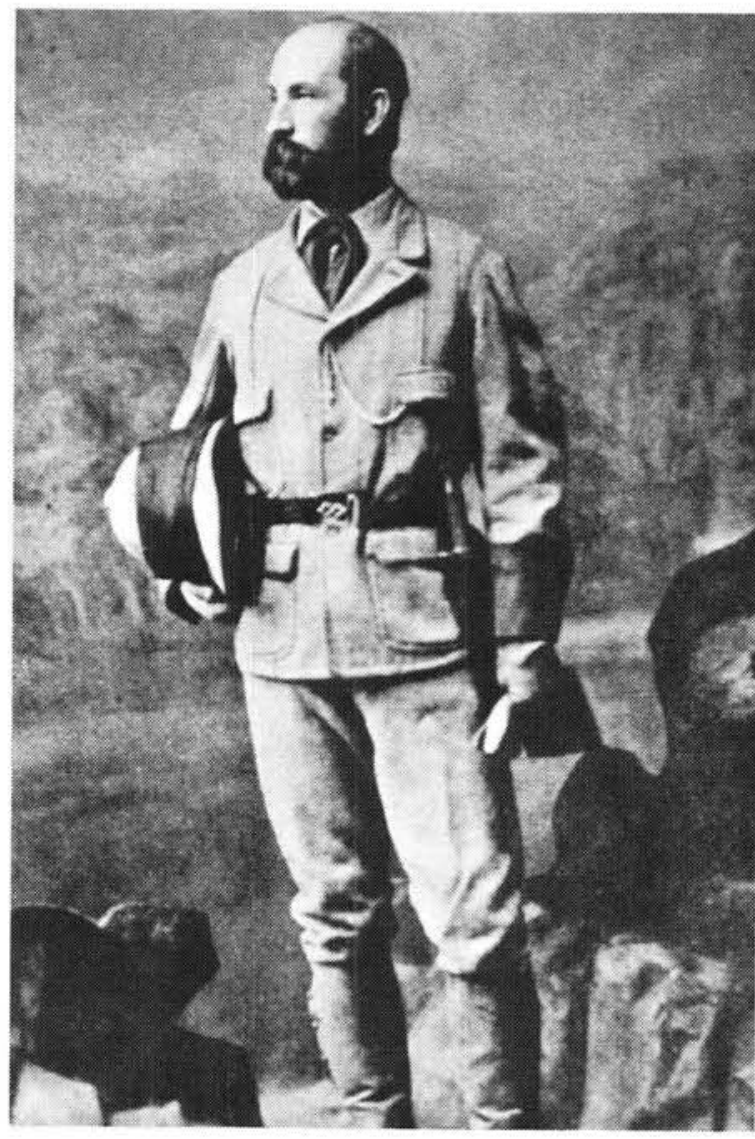

Maj-gen Sir George Pomeroy Colley killed on Majuba during the First War of Independence, 1880-1881

\section{Second War of Independence (1899-1902)}

Deteriorating relations between the South African Republic and Britain finally culminated in war in 1899. There ensued a conflict of almost three years in which all of South Africa was involved

\section{Marengo Raid (1907)}

Marengo, a Khoikhoi guerrilla leader who had given the German authorities a great deal of trouble sought refuge in the Cape Colony in 1906. After a brief spell in prison Marengo began collecting a band again in 1907, and the Cape authorities decided to intervene with the assistance of the Germans across the border. Eventually Marengo was killed in a short clash some 90 miles north-west of Upington in which the Cape forces lost one and six of Marengo's band 


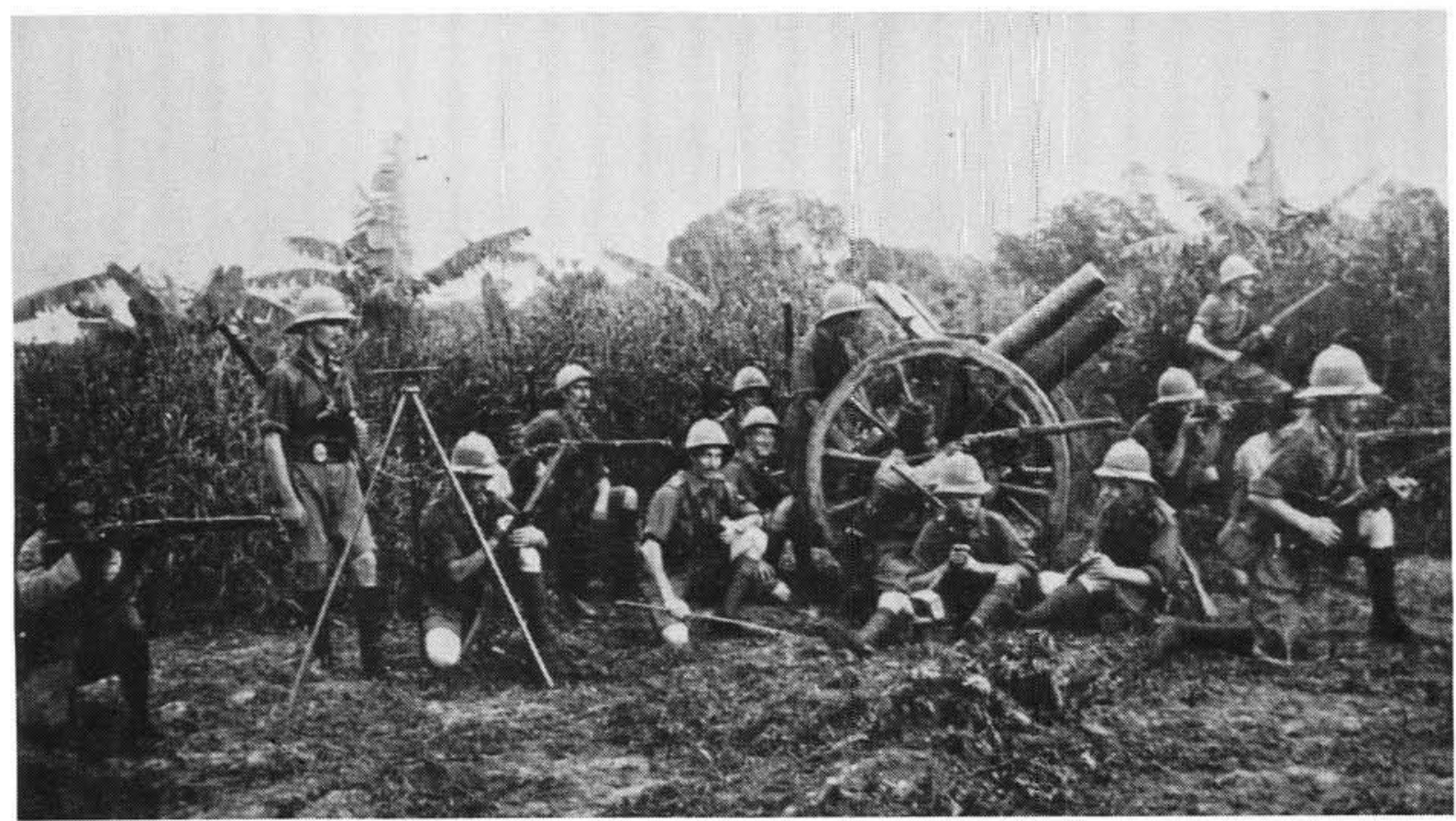

Troops and Howitzer canon: South West Africa 1915

\section{1st World War (1914-1918)}

Though most of the fighting naturally took place outside the Union, even as far as the South African forces were concerned, certain engagements did occur on Union soil. During the German South West Africa campaign the Union De- fence Forces defeated the German Schultztuppe. The campaign started in September 1914 but was hampered by the Rebellion, and in January 1914 it was restarted. It continued untill 9 July 1915 when the German forces surrendered.

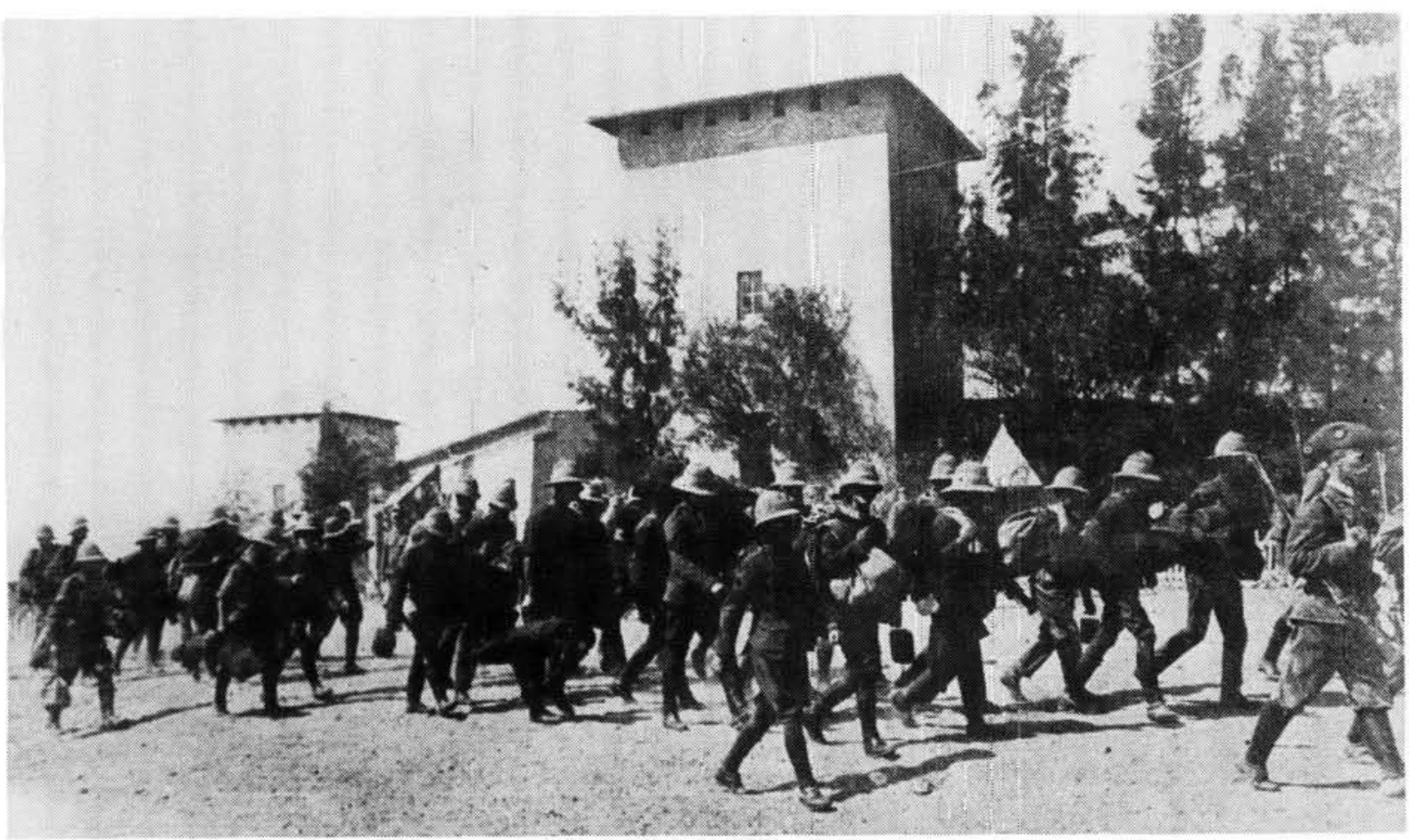

Troops take control of a town in South West Africa: 1914 
- German East Africa and Palestine: Before the war was over, 50000 South Africans of all races volunteerd to serve in East Africa and Palestine.

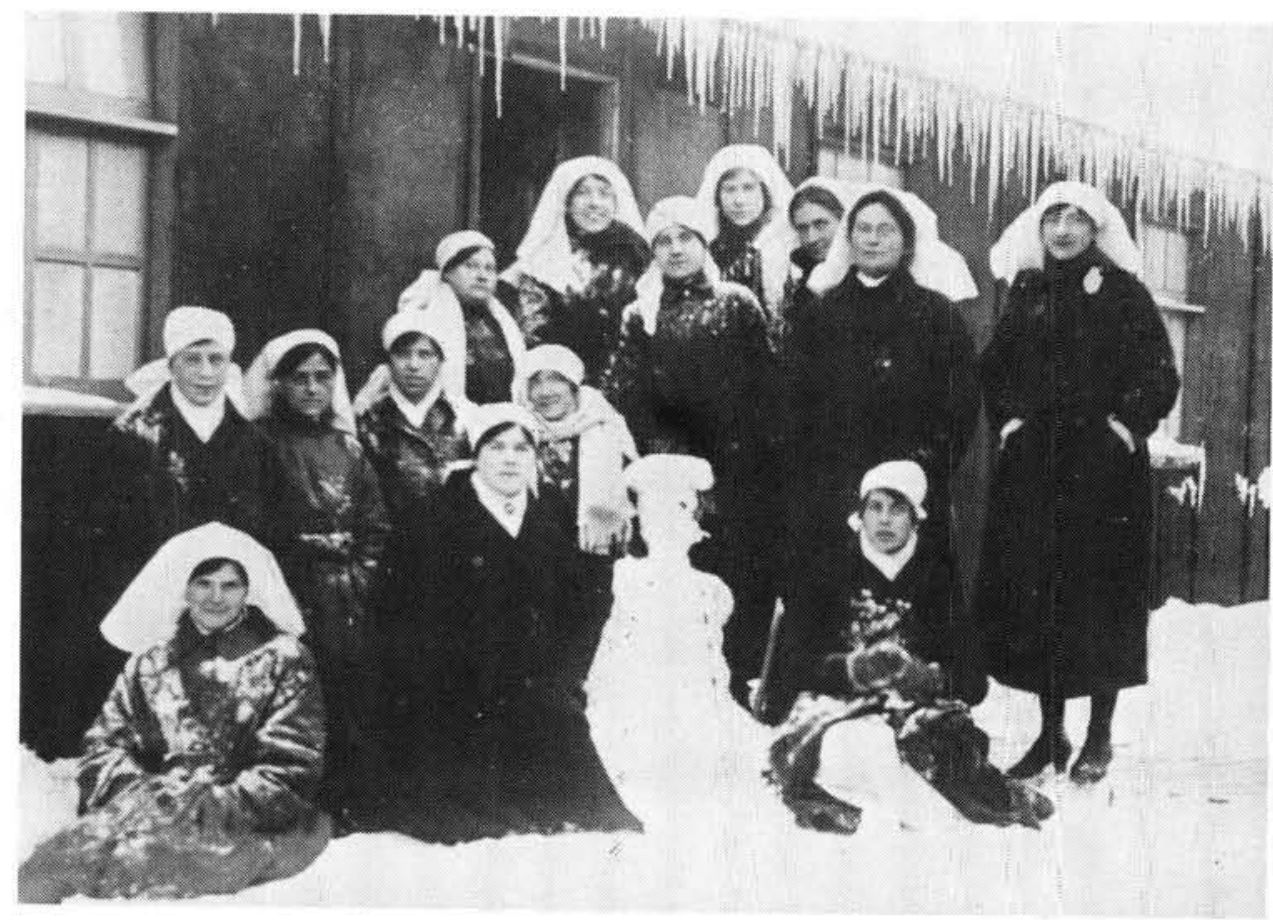

South African nurses in France during the First World War

- France: In France the South Africans made their greatest contribution. Between April 1916 and November 1918 the South African unit suffered some 1400 casualties. Of all the battles fought "Delville Wood" is the one best remembered.

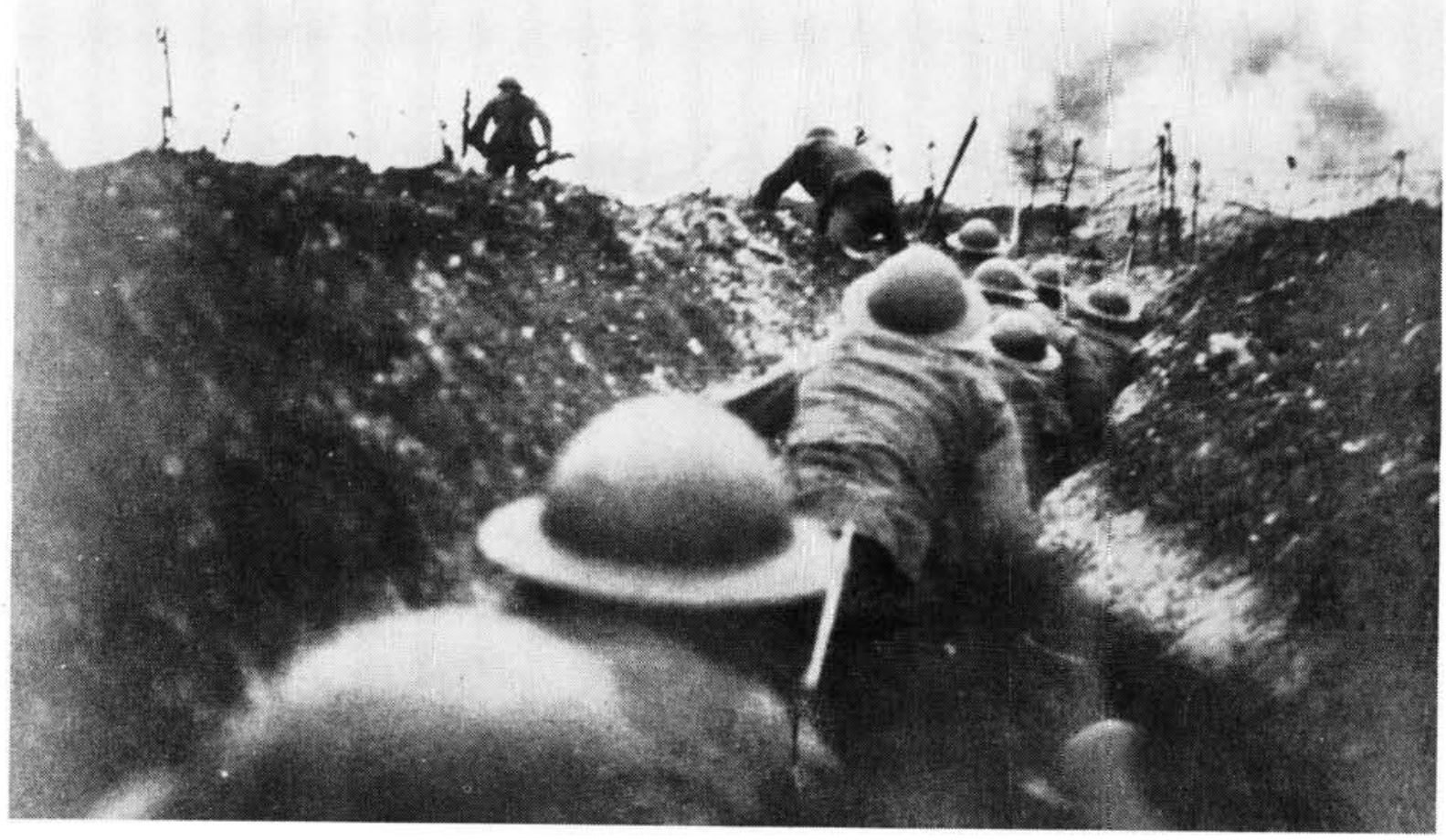

Trench war in France during the First World War 


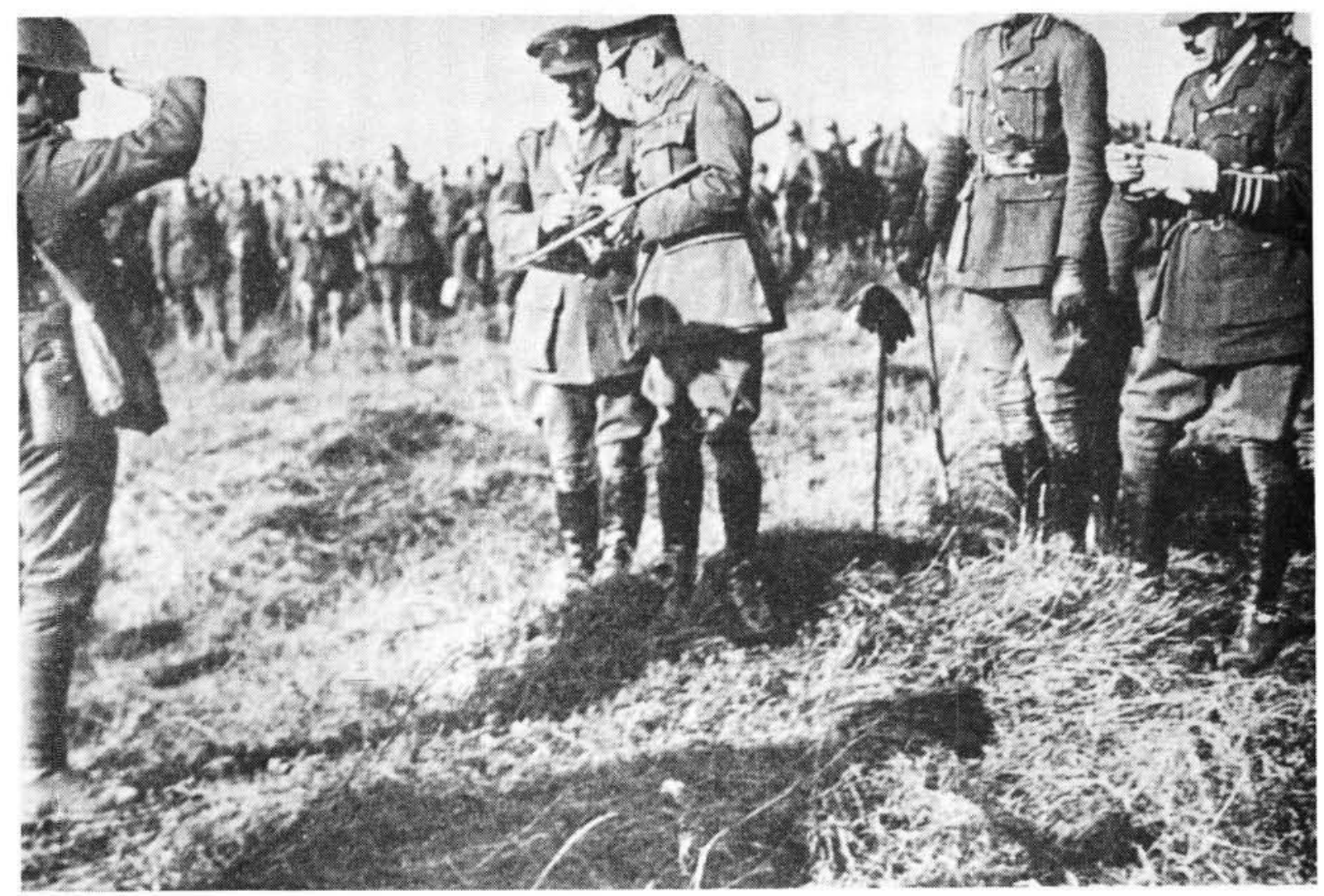

Maj-gen Sir H.T. Lukin presenting decorations at the Delville Wood Memorial service on 17 February 1918

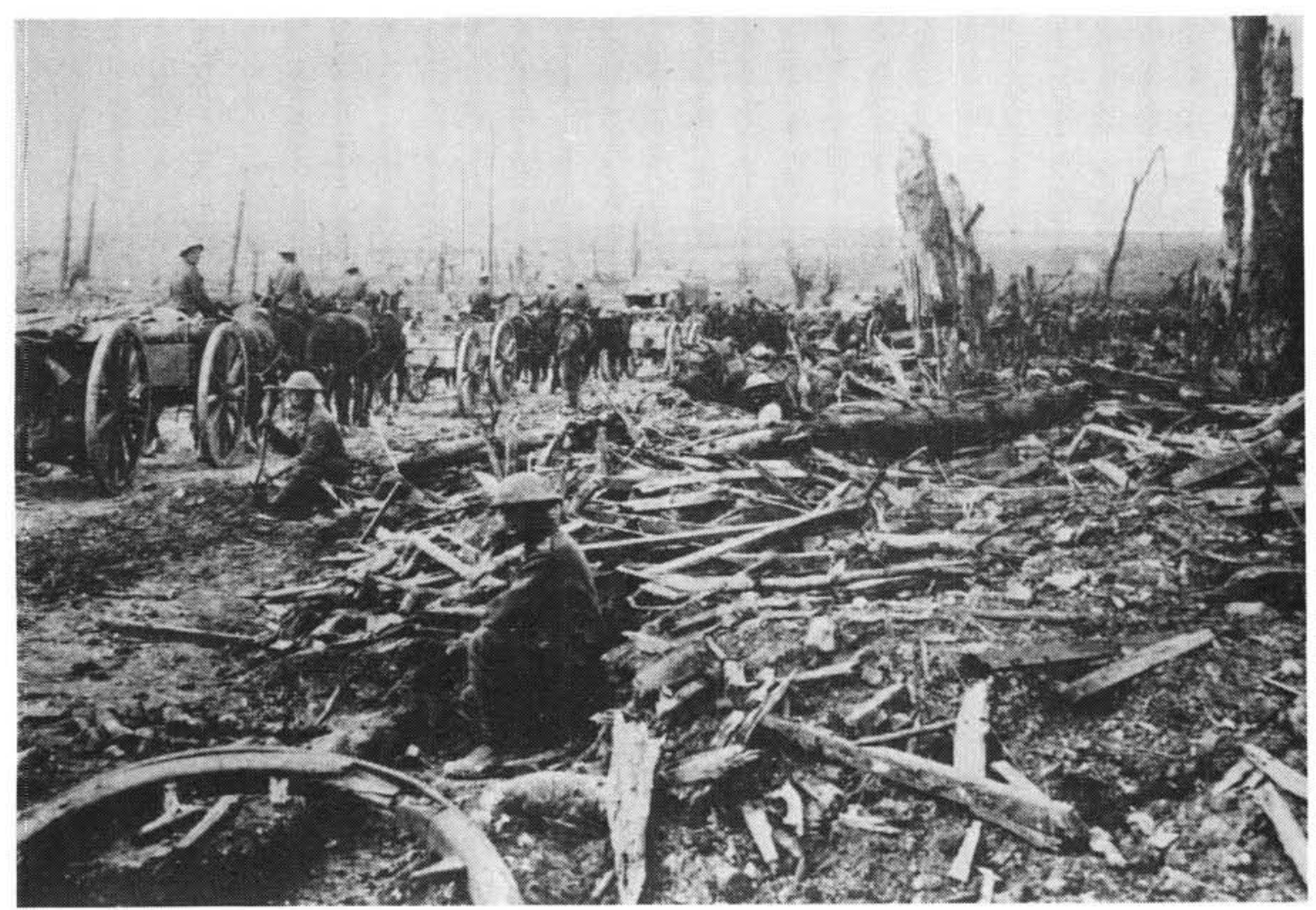

Field Guns moving up through Delville Wood, 15 September 1916 


\section{The Rand Revolt (1922)}

Growing discontent among white miners about the introduction of black workers into semi-skilled employment flared into violence in 1922. White strikers formed commandos and only after a great deal of bloodshed on both sides did government forces succeed in suppressing the rising.

\section{2nd World War (1939-1945)}

The South African Government supported the Allied efforts in Africa, Italy and Madagascar.

\section{German East Africa}

The best know campaigns were:

- Ell Wakl

- The Juba

- The Juba drive

The South Africans suffered 270 casualties:

- Mega

- Addis Ababa

- Dessie

- Amba Alaji

- Mere

- Gonder

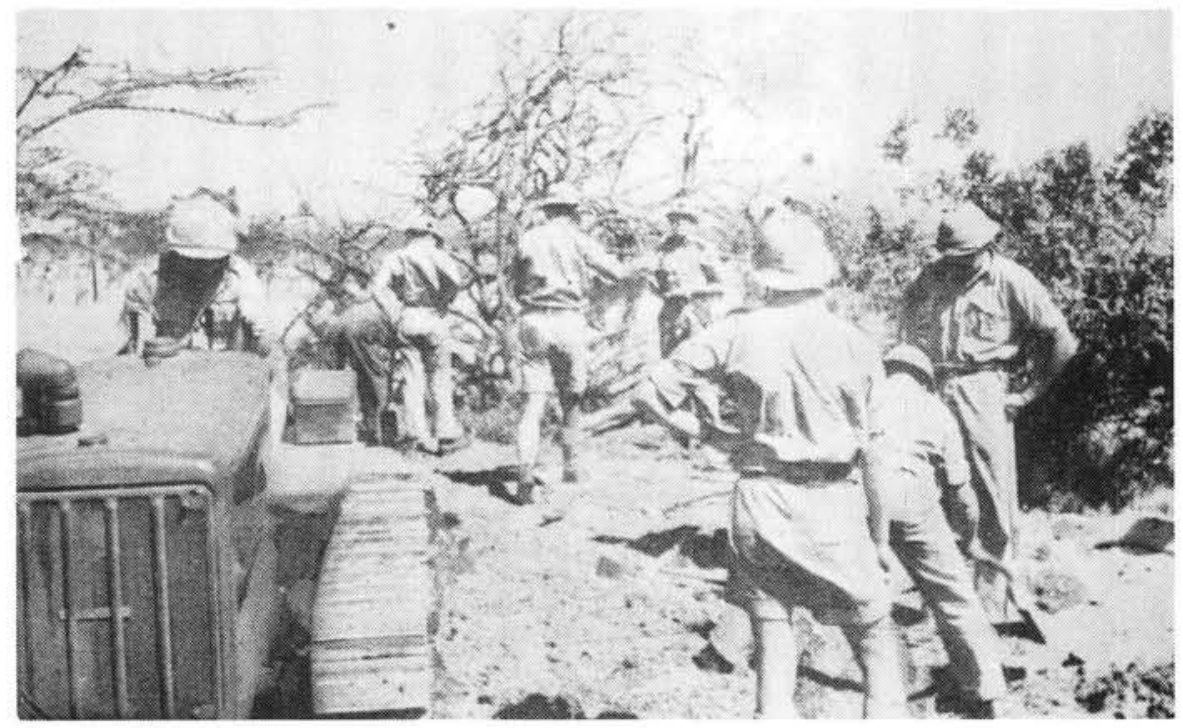

South African Engineers clearing a landing field on the Kenya Border early 1941

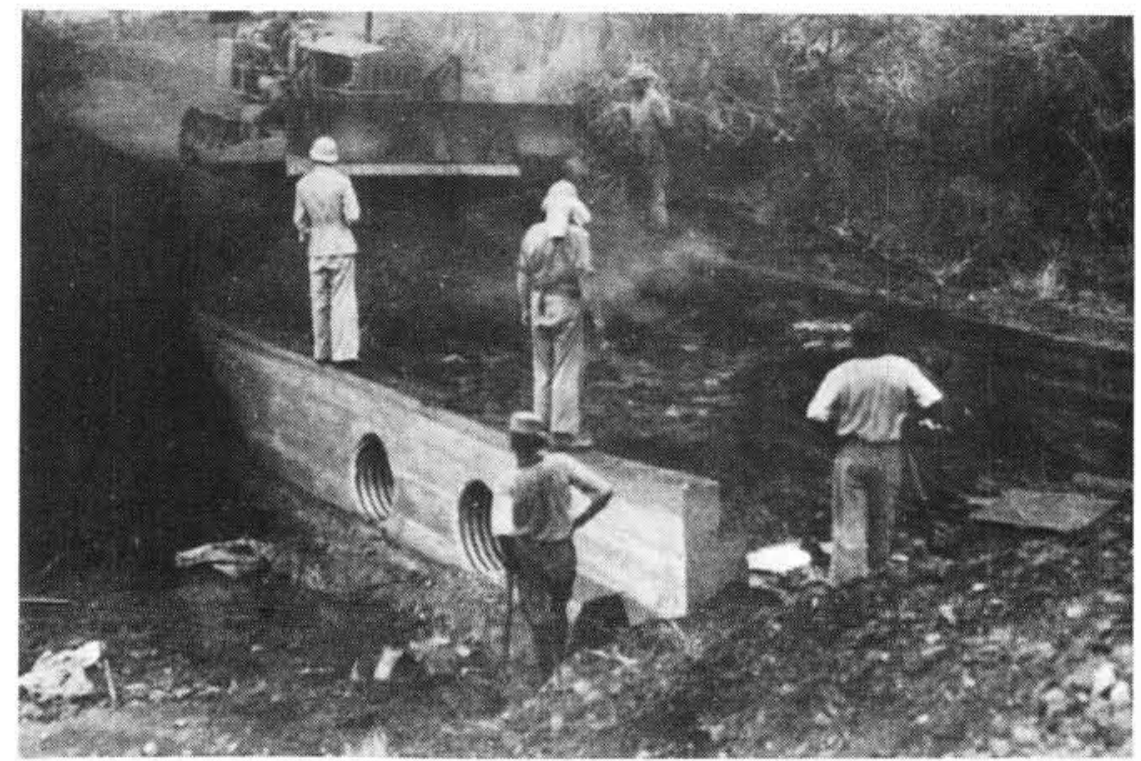

No fewer than 7 South African Roads companies served in East Africa. Some of their Sappers are seen here constructing a culvert 


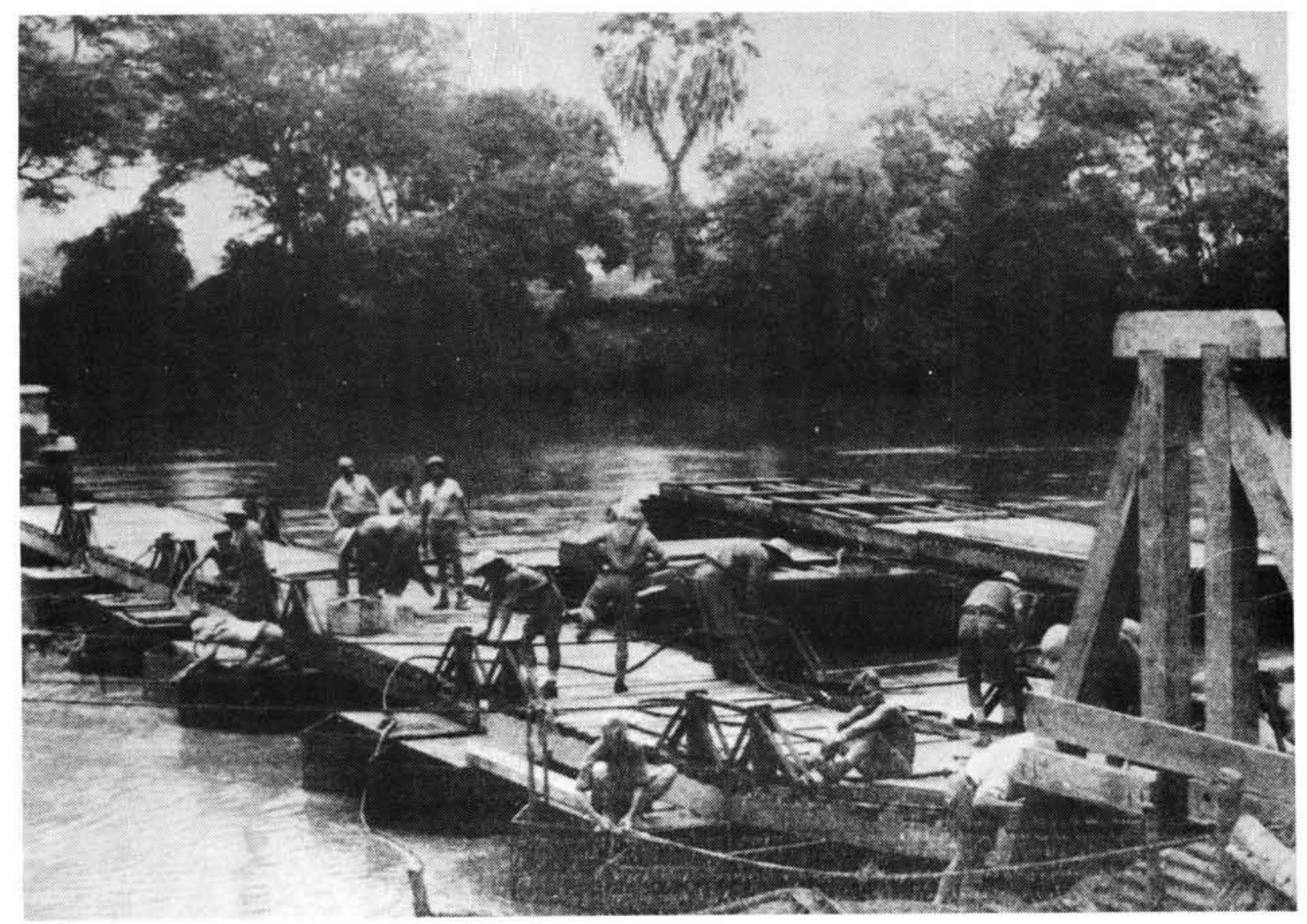

The first pontoon bridges built by South Africans in Kenya, mid-June 1940 by 16 Field Company

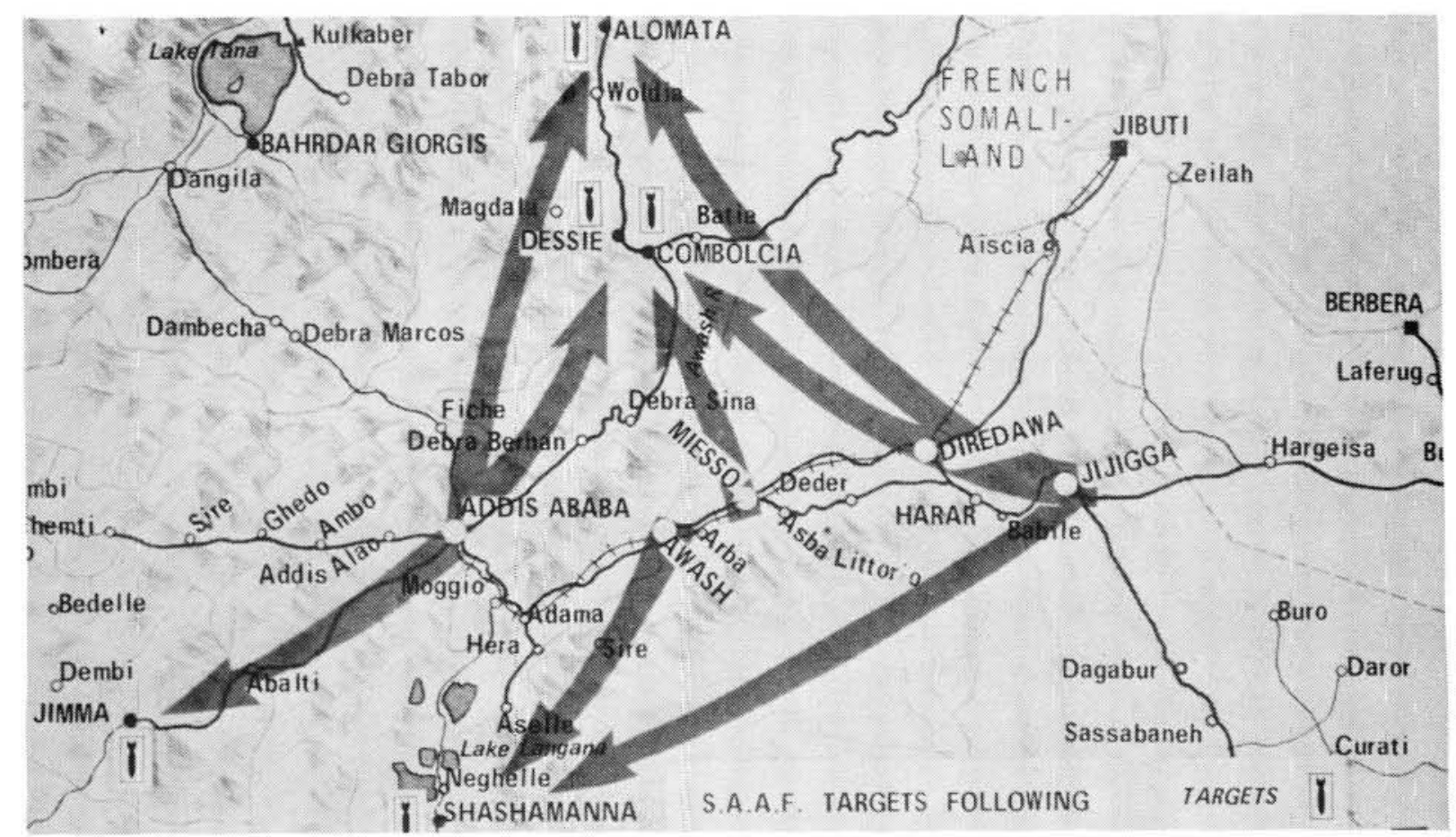

SA Air Force Targets following the fall of Addis Ababa 


\section{North Africa}

Started in 1941, the South African fought in the following campaigns:

- Sidi Rezegh

- Tobruk
- Bardia

- Sollum

- El Alamein

- Gazala

The South Africans suffered 23625 casualties.

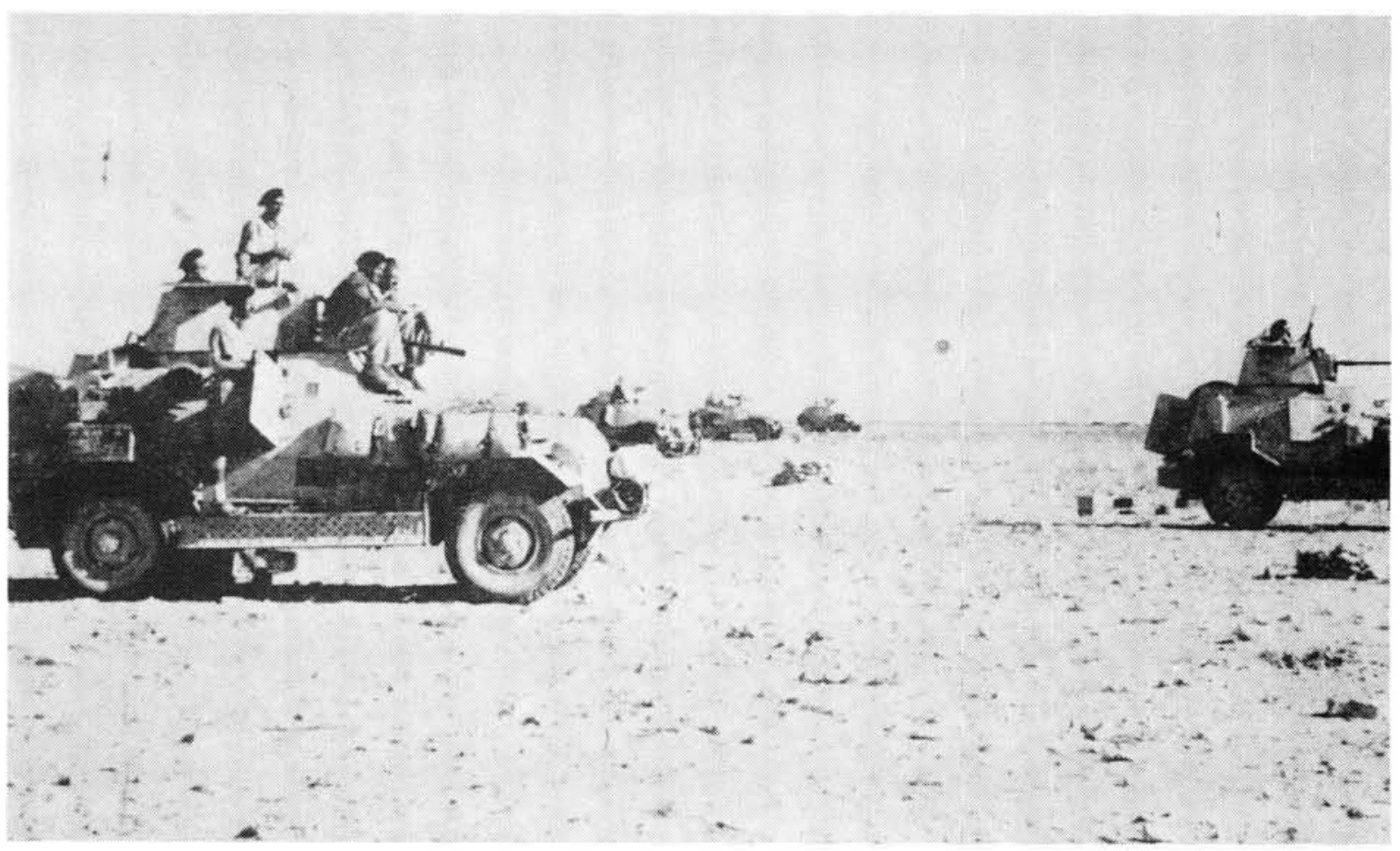

SA Armoured Cars at the halt in the desert of North Africa

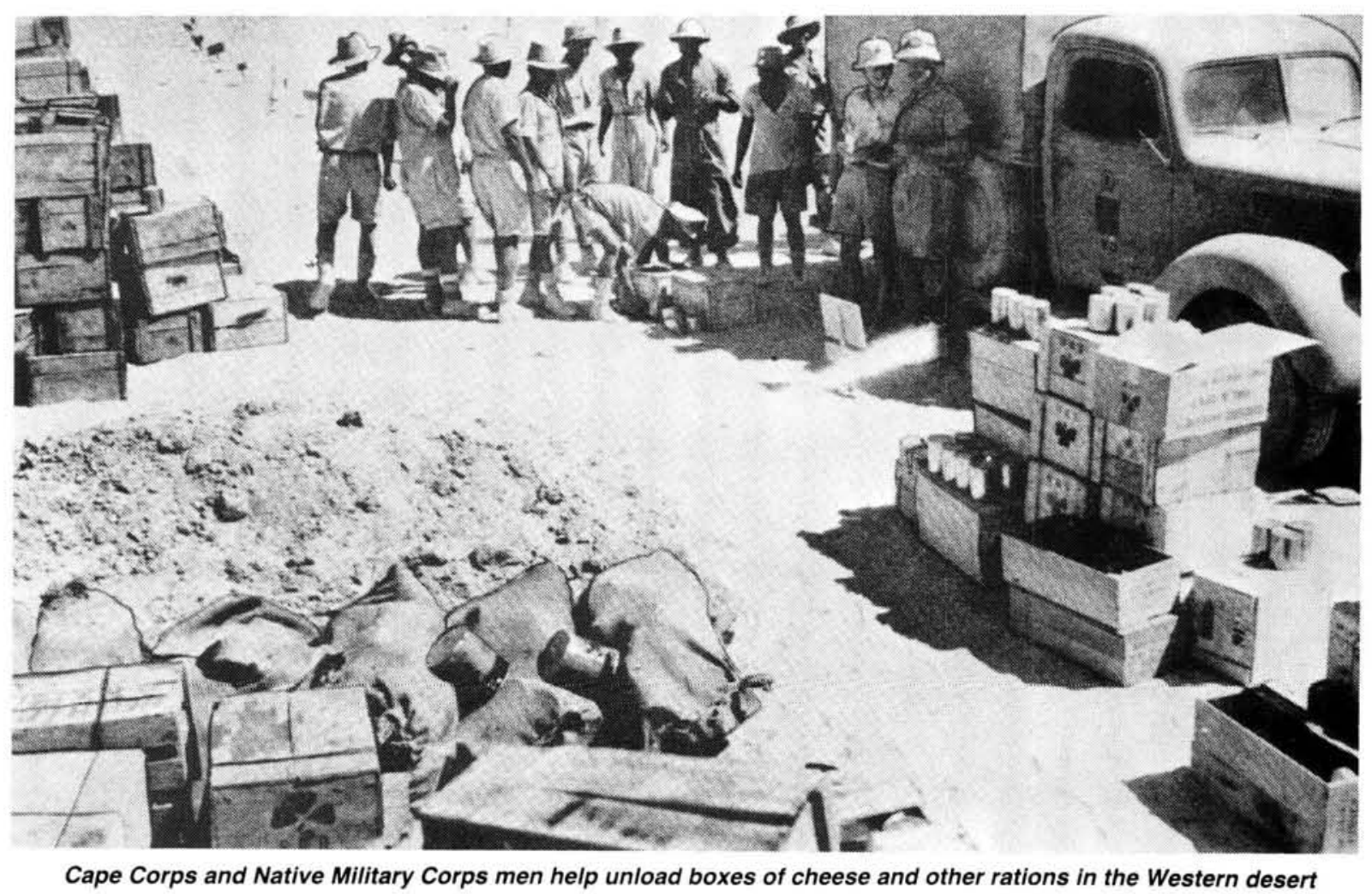




\section{Madagascar}

On 25 June 1942 the South African regiment arrived at Diega Tuarey and supported the Allied effort until 2 November 1942. The Union Defence Forces suffered 18 casualties.

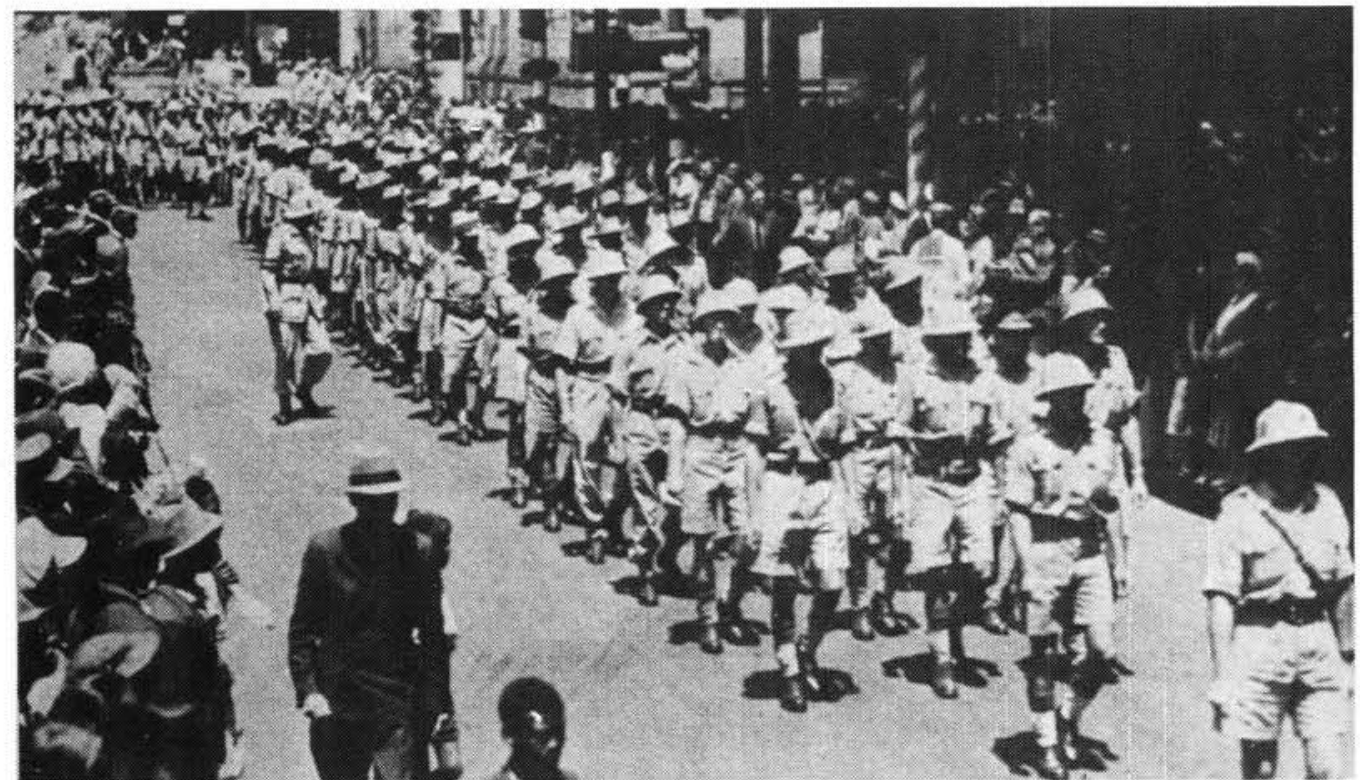

South African troops marching through Cape Town on their return from Madagascar, the occupation of which during the latter half of 1942 represented the only active operations undertaken by the SA Infantry Brigade Group, which was part of 3rd SA Division

\section{Italy}

The 6th Armoured Car Division left for Italy in April 1944. Served until May 1945 when the German forces surrendered. Suffered 5176 casualties.

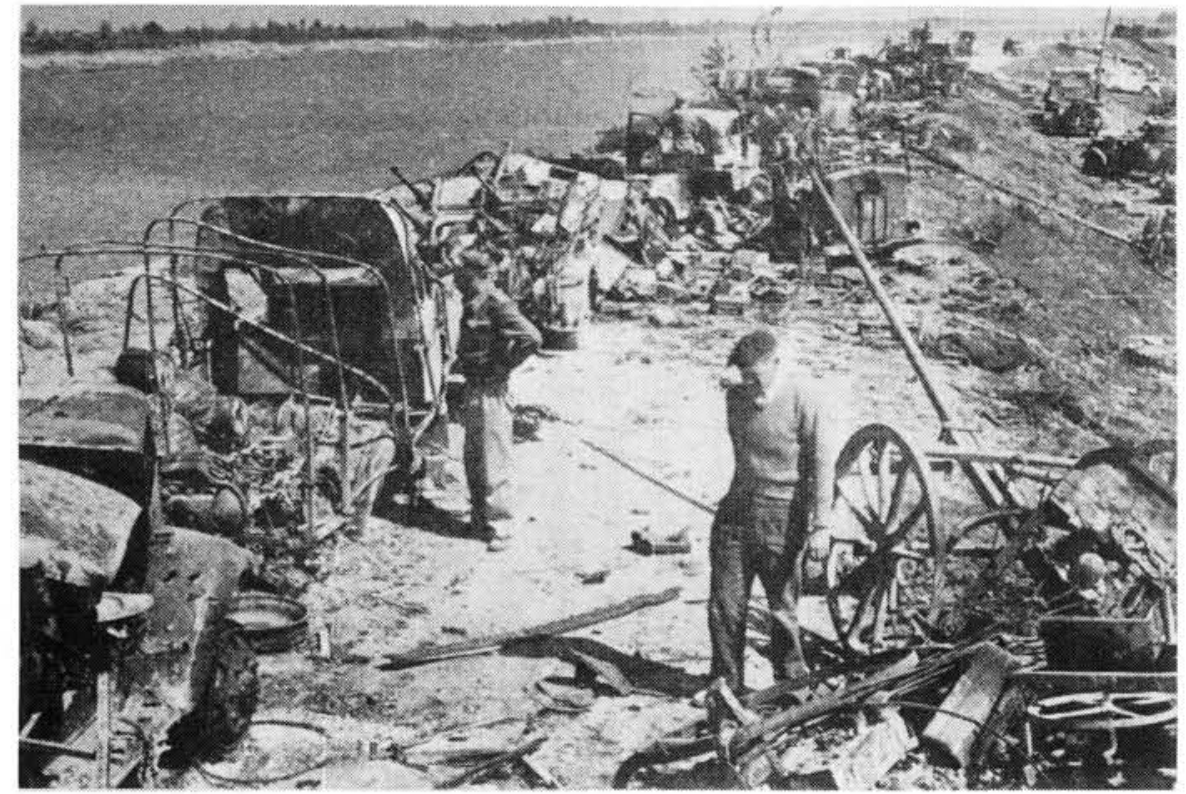

Strewn along the banks of the Po were hundreds of enemy vehicles of all descriptions destroyed by air attacks, fire from artillery and tanks on by the enemy himself during his retreat 


\section{Korea (1950-1953)}

2 Squadron participated as part of the United Nations forces in Korea against the Chinese Communists.

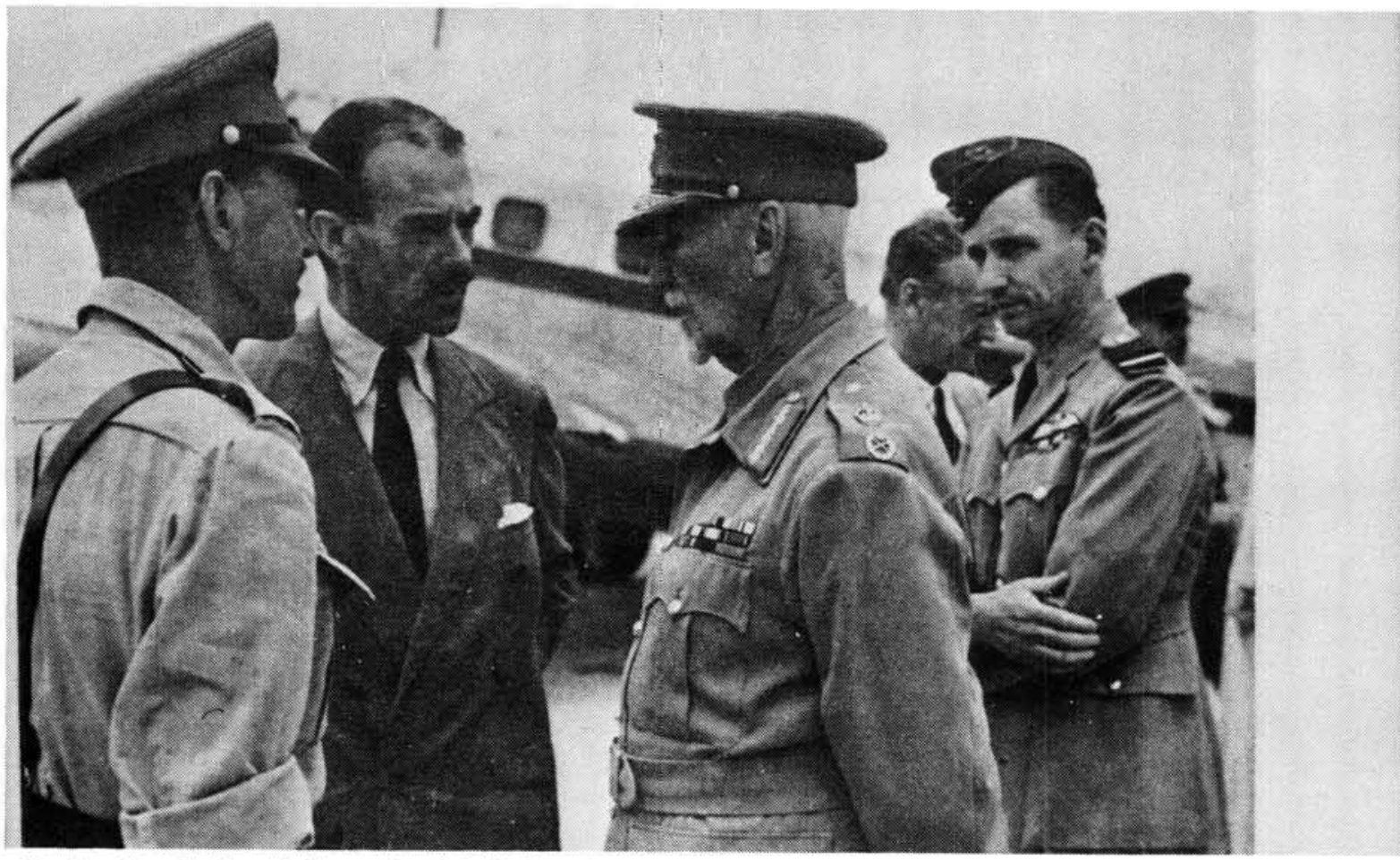

Gen the Hon Sir Harold Alexander, C-in-C, Middle East in succession to Gen Auchinleck, the Rt Hon R.G. Casey, Field Marshal Smuts and Air Chief Marshal Sir Arthur W. Tedder, Air Officer C-in-C, Middle East

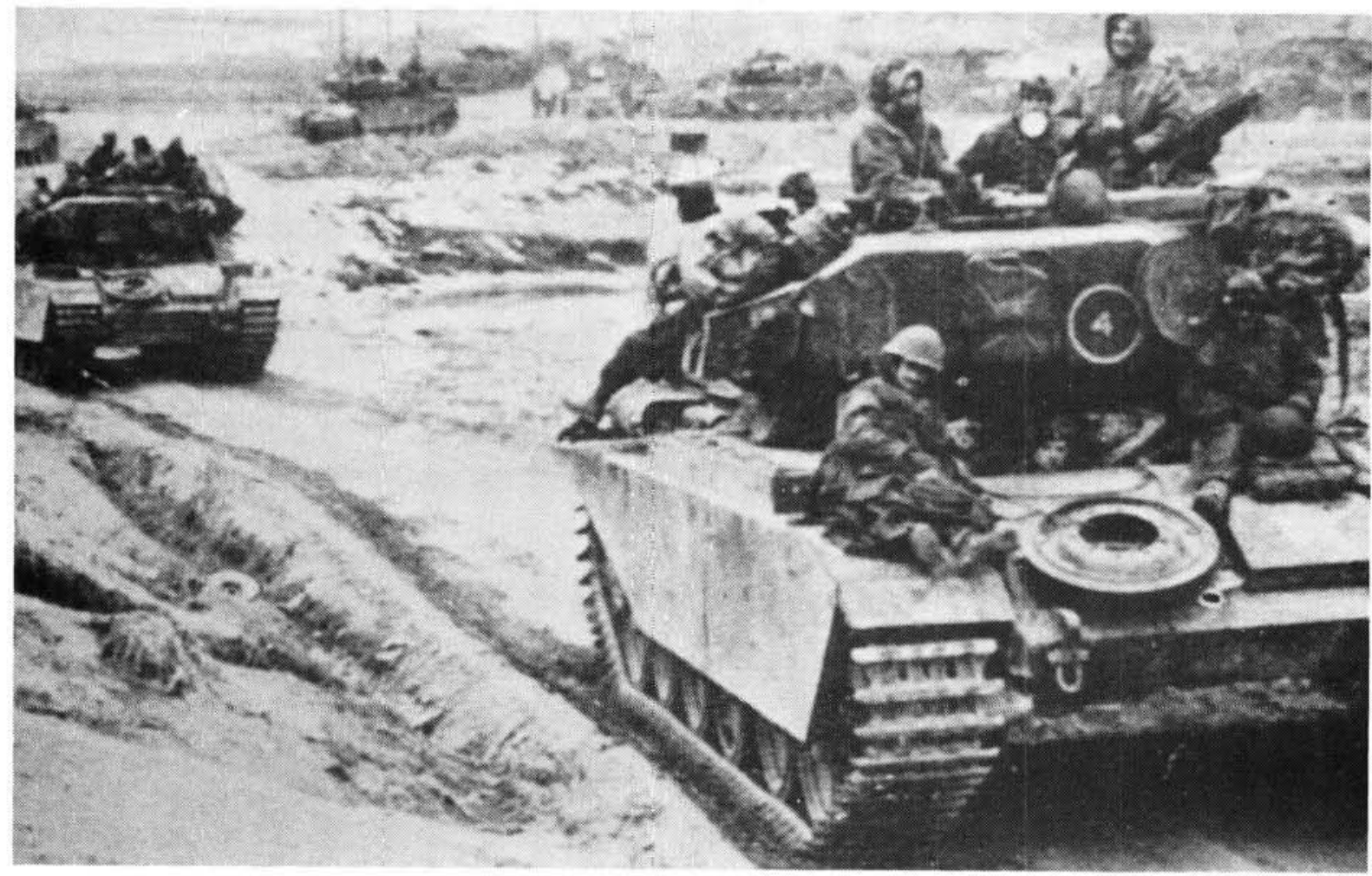

Korea 1950. Centurion Tanks of the 8th Hussars 


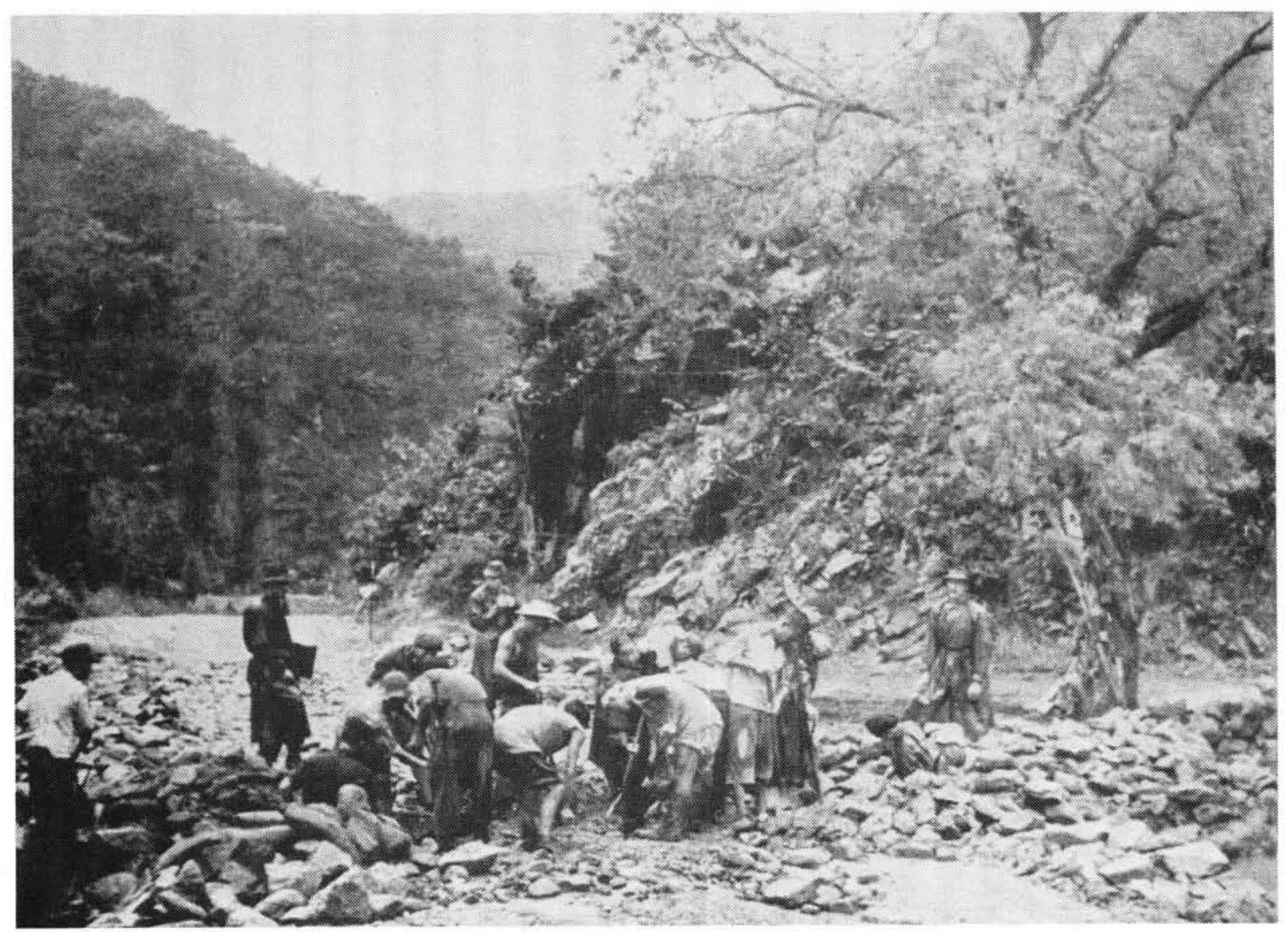

Korea Jun-Nov 1950. Repairing a road near Imjin River

\section{Angolan War (1975-1976)}

In 1975 the South African Defence Force joined forces with UNITA and FNLA against the MPLA supported by Cuban forces. In 1976 the South African forces withdrew from Central Angola.

\section{Operations to combat terrorism}

Since the early seventies elements of the South African Security Forces had from time to time been deployed in counter-insurgency operations against the South West People's Organization (SWAPO) in the North of South West Africa. Some of the major cross-border operations undertaken against terrorist bases in Southern Angola, include Reindeer (1978), Protea (1981) and Askari (1984). In South Africa the Security Forces have been particularly successful in the suppression of subversive activities of the Communist-backed African Nationalist Congress (ANC). 


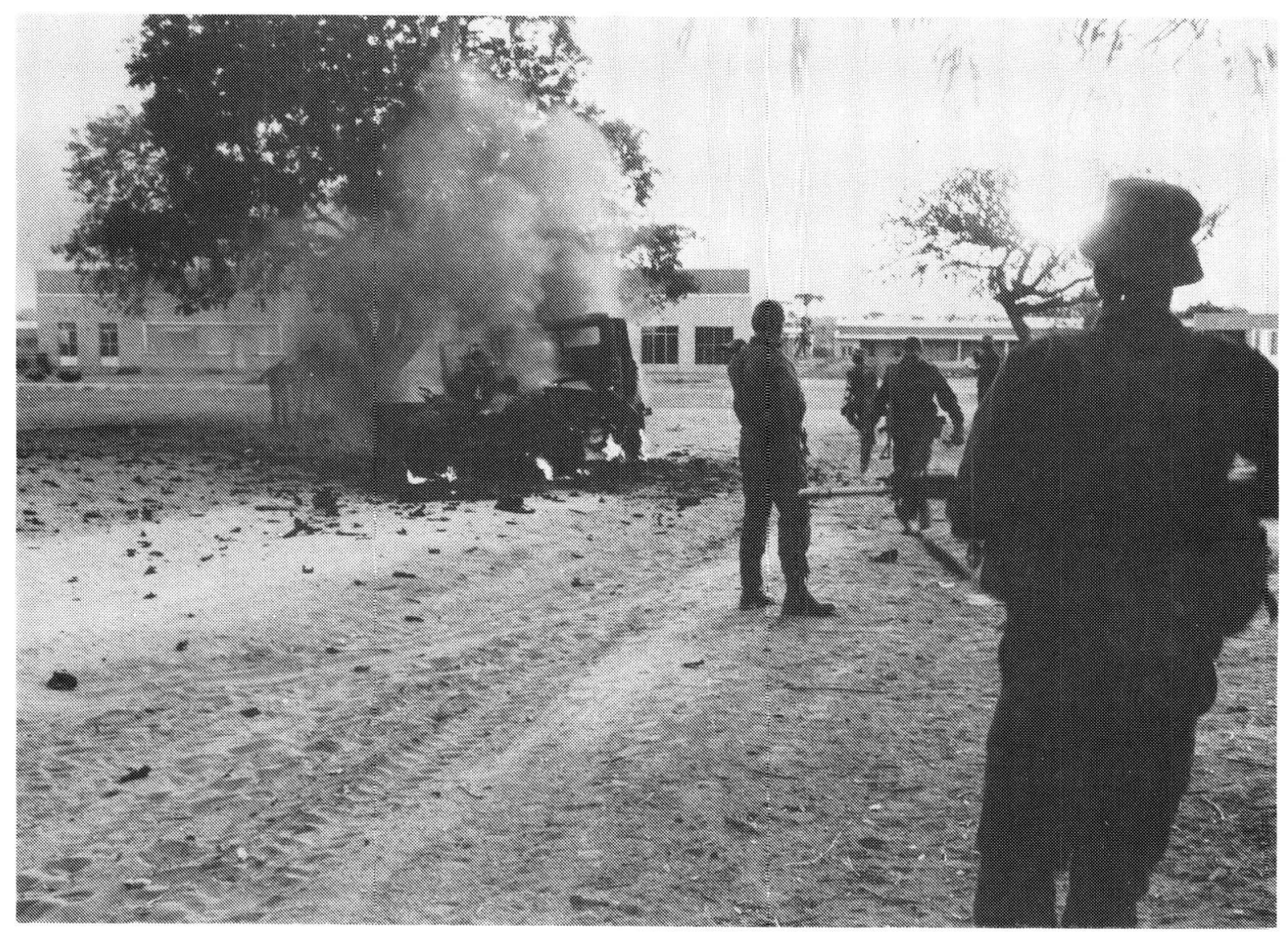

\section{South African Soldiers in Angola}

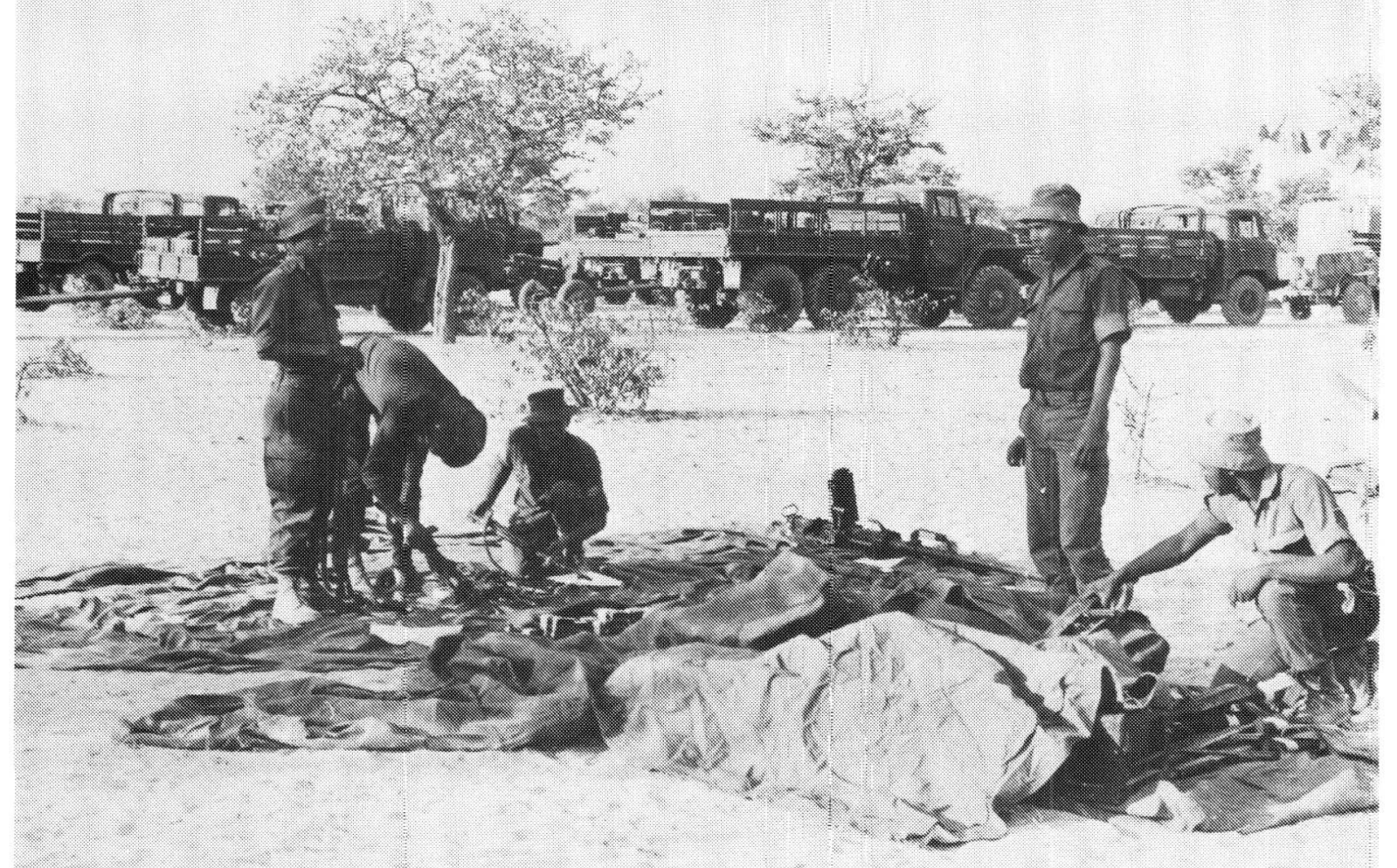




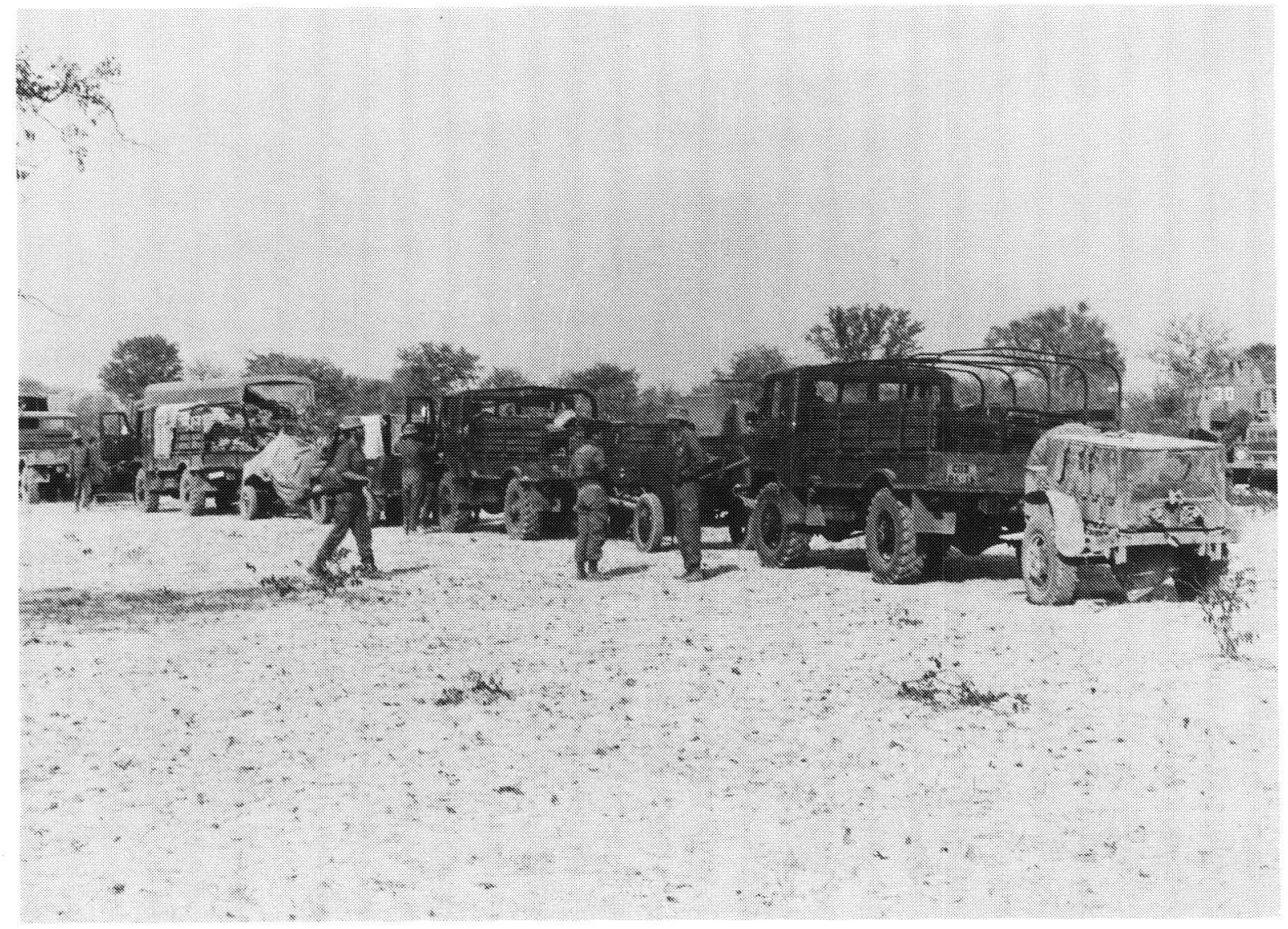

South African Soldiers in Angola 


\section{Monumente en gedenktekens op Weermagsterreine}

\section{Kol F Oelschig*}

Daar is twee gedenktekens op die Grahamstad Militêre Basis terrein, naamlik die "Savannah Shellhole" (MOTH) gedenkteken en die 6 SAI Bn gedenkteken.

\section{MOTH Gedenkteken}

Die "Savannah Shellhole" gedenkteken is opgerig deur die MOTH organisasie van Grahamstad
Militêre Basis om die gesneuweldes van die Grahamstad eenhede (6 SAI Bn, 84 TVD, First City Regt en Midland Komdo) te gedenk.

Die gedenkteken is onthul deur Kol Bailey op 9 Nov 1979 en 'n gedenkdiens word jaarliks in Oktober gehou deur verteenwoordigers van al die plaaslike eenhede en oudgediende organisasies.

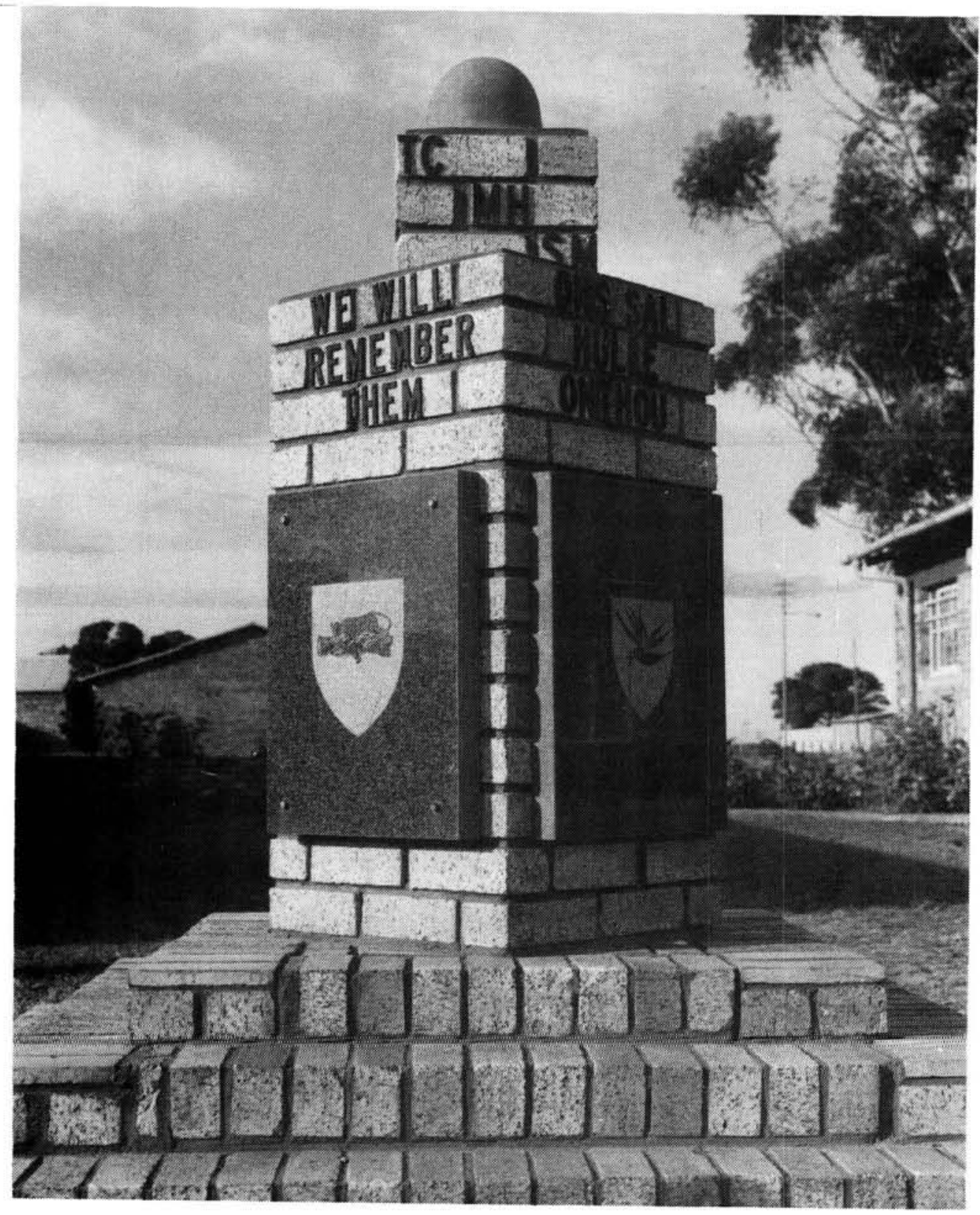

